\title{
THE LIQUIDITY COST OF PRIVATE EQUITY INVESTMENTS: EVIDENCE FROM SECONDARY MARKET TRANSACTIONS
}

\author{
Taylor D. Nadauld \\ Berk A. Sensoy \\ Keith Vorkink \\ Michael S. Weisbach \\ Working Paper 22404 \\ http://www.nber.org/papers/w22404
NATIONAL BUREAU OF ECONOMIC RESEARCH
1050 Massachusetts Avenue
Cambridge, MA 02138
July 2016

We are extremely grateful to the partners at an anonymous intermediary for providing us with data. We thank Steven Davidoff, Josh Lerner, Ludovic Phalippou, David Robinson, Weiling Song, Per Stromberg, and seminar participants at Amsterdam, NHH Bergen, Ohio State, Stockholm, Texas, and Tilburg for helpful suggestions. Greg Adams, Shan Ge, and Dongxu Li provided excellent research assistance. The views expressed herein are those of the authors and do not necessarily reflect the views of the National Bureau of Economic Research.

NBER working papers are circulated for discussion and comment purposes. They have not been peer-reviewed or been subject to the review by the NBER Board of Directors that accompanies official NBER publications.

(C) 2016 by Taylor D. Nadauld, Berk A. Sensoy, Keith Vorkink, and Michael S. Weisbach. All rights reserved. Short sections of text, not to exceed two paragraphs, may be quoted without explicit permission provided that full credit, including () notice, is given to the source. 
The Liquidity Cost of Private Equity Investments: Evidence from Secondary Market Transactions Taylor D. Nadauld, Berk A. Sensoy, Keith Vorkink, and Michael S. Weisbach

NBER Working Paper No. 22404

July 2016

JEL No. G11,G23,G24

\section{ABSTRACT}

An important cost of investing in private equity is the illiquidity of these investments. In response to this illiquidity, a secondary market for transacting stakes in private equity funds has developed. This paper uses proprietary data from a leading intermediary to understand the magnitude and determinants of transaction costs in this market. Most transactions occur at a discount to net asset value. Buyers average an annualized Public Market Equivalent (PME) of 1.023 compared to 0.974 for sellers, implying that buyers outperform sellers by a market-adjusted five percentage points annually. For the most common type of transaction, the sale of stakes in funds four to nine years old, the difference is smaller, about three percentage points. Both the discount to NAV and the difference in returns between buyers and sellers returns appear to be related to factors associated with asymmetric information and market depth. Buyers in this market tend to be funds-of-funds, while sellers are more likely to be traditional private equity investors such as endowments and pension funds.

Taylor D. Nadauld

Department of Finance

Brigham Young University

Provo, Utah 84602

taylor.nadauld@byu.edu

Berk A. Sensoy

Ohio State University

2100 Neil Ave.

Columbus, $\mathrm{OH} 43210$

sensoy.4@osu.edu

\author{
Keith Vorkink \\ Finance Department \\ Marriott School \\ Brigham Young University \\ Office 634 TNRB \\ Provo, UT 84602-3113 \\ keith_vorkink@byu.edu \\ Michael S. Weisbach \\ Department of Finance \\ Fisher College of Business \\ Ohio State University \\ 2100 Neil Ave. \\ Columbus, $\mathrm{OH} 43210$ \\ and NBER \\ weisbach.2@osu.edu
}




\section{Introduction}

An important cost of investing in private equity funds at inception is that an investor must commit his capital for a fund's entire life, typically ten to twelve years. During the period in which the capital is invested, an investor in a private equity fund does not have access to the invested capital, and is committed to provide capital on demand by the general partner (GP) for the fund's future investments. Consequently, investments in private equity funds are less liquid than many alternative investments. Industry practitioners frequently cite the illiquidity of private equity investments among the most important risks that investors should consider when making these investments (see for example EVCA, 2013).

In recent years, a market has developed in which investors can buy and sell limited partner (LP) stakes in private equity funds. This market alleviates to some extent the illiquidity of private equity investments as it allows investors to exit their commitments. In a transaction in this market, the buyer pays the seller for the portion of his commitment that has already been drawn down and assumes the obligation to participate in all future investments and to pay all future management fees. In return, the buyer receives the right to all future distributions from exits of the fund's current investments.

Using privately obtained data on transactions in the secondary market for private equity funds from a leading intermediary in this market, we measure the average cost of transacting from both buyer and seller perspectives. These data cover all transactions intermediated by this broker during the 2006-2014 time period and all of the bids they received on transactions subsequent to 2010 .

We begin by examining the discounts or premiums relative to "Net Asset Value" (NAV) at which these transactions occur. A fund's NAV is the valuation that the fund reports to its investors, and deviations from NAV are generally used by practitioners to measure any discount or premium on a sale of a stake in a fund. In our sample, transactions occur on average at a discount to NAV for all types of funds that are transacted in the secondary market, including buyout funds, venture capital funds, real estate funds, and funds of funds. The average discount over the full sample is $13.8 \%$ of NAV, though this discount varies with fund age and overall market conditions. The $13.8 \%$ average for the full sample reflects, in part, deep discounts that occurred with the sale of very young funds during the financial crisis, and some very old 
funds after the crisis. The most common type of transaction in our sample is for a fund between 4 and 9 years old and has an average discount to NAV of around $9 \%$.

Because NAVs in private equity funds are not a market-based assessment of the fund's underlying value, and because the literature finds that NAVs are sometimes manipulated by GPs, we construct a second measure of the cost of secondary sales. Using data on the cash flow distributions of the funds, we calculate the annualized returns to investors who buy and sell the funds on the secondary market. Despite the discounts to NAV they accept, sellers potentially could outperform buyers by this measure if they are able to systematically sell funds at higher prices than justified by their future prospects. This could occur if existing LPs have valuable soft information (as opposed to the hard information provided to potential buyers as part of the due diligence process surrounding these transactions) that potential buyers do not. However, the data suggest that the buyers in these transactions outperform sellers, again suggesting that transaction prices occur at a discount to the funds' underlying values. Buyers who purchase a fund through the secondary market and hold the fund to liquidation earn higher returns than sellers, on average. The most common type of transaction in our sample is associated with average (median) annualized buyer IRRs of $19.8 \%(15.6 \%)$. In comparison, average (median) annualized seller IRRs for the most common type of transaction are $2.1 \%(2.4 \%)$. Consistent with variation in NAV discounts, differences in buyer and seller IRRs vary substantially with the age of the fund at the time of transaction.

Larger IRRs for buyers relative to sellers could potentially reflect other factors, aside from liquidity costs. One possibility is the fact that sellers tended to hold their positions during worse economic times (around the financial crisis), while buyers are more likely to have held their positions during the 2010-2014 period, when financial markets performed better. To adjust for such market wide factors, we compute annualized public market equivalents (PMEs) for buyers and sellers. ${ }^{1}$ In the full sample, buyer annualized

\footnotetext{
${ }^{1}$ The PME is equal to the ratio of the sum of discounted cash distributions from the fund to investors to the sum of discounted cash provided by investors to the fund, where the discount rate is the cumulative return on the public equity market from the inception of the fund to the cash flow in question. A ratio greater than one indicates outperformance relative to the public equity benchmark. Kaplan and Schoar (2005) are the first to use this market-adjusted performance measure in the empirical literature. Korteweg and Nagel (2016) and Sorensen and Jagannathan (2015) examine the
} 
PMEs average 1.023 compared to average seller annualized PMEs of 0.974 , consistent with the IRR results suggesting that buyers do outperform sellers by about 5 percentage points per year. Annualized PMEs for funds between 4 and 9 years old, the most common transaction type, are 1.013 for buyers and 0.983 for sellers. These calculations imply that for the most common type of transaction in this market, sales of funds between 4 and 9 years old, buyers outperform sellers by about 3 percentage points per year that they are held. The fact that differences in annualized PMEs are so much smaller than differences in IRRs underscores the importance of adjusting returns for market conditions over the life of the fund.

Both the discounts to NAV and the difference in returns to buyers and sellers are measures of the cost of transacting in the secondary market. Aside from fund age explanations, these costs are associated with other factors that are consistent with theories of market microstructure, including the amount of asymmetric information in the market. Consistent with theories of asymmetric information, NAV discounts are larger for smaller funds. Transaction discounts to NAV and the difference between buyer and seller returns also tend to be larger when the economy is doing poorly and there is less capital available to purchase the stakes. Finally, discounts are larger for smaller transactions, for which the information costs per dollar invested are higher.

Institutional investors differ from one another in a number of ways, an important one of which is the extent to which their operations depend on the cash flows produced by their investments. For example, traditional investors such as endowments and pension funds rely on their private equity investments to generate cash flow via distributions that is used by their organization and also are subject to periodic liquidity shocks. Most of the sellers in our sample are this type of investor, consistent with unexpected liquidity needs or changing portfolio strategies. Most of the buyers in our sample are funds of funds, which are increasingly formed for the express purpose of acquiring stakes on the secondary market. In our sample, of the 2,173 buy transactions for which we know the LP type, 1,862 (85.7\%) of the buyers were a fund of funds. Although our results indicate that sellers in the secondary market earn lower returns than secondary

theoretical validity of the PME. In this paper we annualize PMEs to compare returns over different horizons (i.e., buyer and seller holding periods generally differ). 
market buyers, on average, increased activity in the secondary market as a whole is consistent with the notion that sellers also benefit from the liquidity afforded by the secondary market.

The secondary market for LP stakes in private equity appears to be one in which buyers receive returns for supplying liquidity. Sellers benefit because they are able to make strategic changes in their portfolios that, given the time horizon of private equity investments, would be impossible in the absence of a secondary market. Because of the cost of transacting in this market, the illiquidity of private equity should be a factor that investors take into account when investing in this sector, even though there is a market through which they can sell their stakes. To the extent that this market becomes more liquid over time, the illiquidity of the underlying private equity investments should become less of an issue to institutional investors making portfolio decisions. The secondary market for the most commonly traded types of fund stakes, those in large funds between four and nine years old, appears to be fairly liquid already, as evidenced by relatively small differences in annualized PMEs between buyers and sellers.

This paper is related to several strands of the existing literature. In its broadest goals, it adds to the theoretical and empirical literature that attempts to understand the risk and return of illiquid or thinly traded assets (see, for example Longstaff, 2014). In private equity, the empirical literature on LP performance so far focuses exclusively on the returns earned by LPs who commit capital at a fund's inception and hold the fund for its entire life. ${ }^{2}$ Although there is substantial heterogeneity in these hold-to-maturity fund returns, our analysis shows that the heterogeneity in LP investment experiences in private equity is even greater than the extant literature would suggest. Bollen and Sensoy (2015) model the way in which the possibility of secondary sales at a discount affects the expected returns LPs require on their commitments to private equity funds. Their analysis suggests that, despite the secondary market discounts documented here, the

\footnotetext{
${ }^{2}$ For estimates of hold-to-maturity private equity fund performance, see Kaplan and Schoar (2005), Ljungqvist, Richardson, and Wolfenzon (2007), Phallippou and Gottschalg (2009), Higson and Stucke (2012), Phalippou (2012), Robinson and Sensoy (2013, 2015), and Harris, Jenkinson, and Kaplan (2014). For estimates of differences in holdto-maturity fund returns across LPs, see Lerner, Schoar, and Wongsunwai (2007), Sensoy, Wang, and Weisbach (2014), and Cavagnaro, Sensoy, Wang and Weisbach (2016).
} 
returns initial LPs in private equity funds receive are often sufficient to compensate for the market and liquidity risks they face.

Prior work by Kleymenova, Talmor and Vasvari (2012) also examines aspects of the secondary market in private equity. Their work focuses on understanding prices bid for LP stakes, but does not analyze actual transactions, and consequently cannot determine the actual prices paid or the returns to buyers and sellers, which are the core of our analysis.

The remainder of this paper proceeds as follows. Section 2 discusses the institutional features of the secondary market for stakes in private equity funds. Section 3 presents statistics on our sample, especially regarding the pricing of the stakes relative to NAV. Section 4 presents statistics on the returns to buyers and sellers in this market. Section 5 examines the cross-sectional pattern of the discounts and the buyer and seller returns. Section 6 documents that the buyers and sellers tend to differ with respect to their reliance on cash flows from their investments, and consequently the flexibility they have regarding their investments. Section 7 discusses institutional features of the market that are relevant in interpreting our results. Section 8 summarizes the results and discusses their implications.

\section{The Secondary Market for Stakes in Private Equity Funds}

\subsection{How Private Equity Funds are Structured}

Private equity funds are limited partnerships in which general partners raise capital from limited partners and make investments in portfolio companies. These portfolio companies vary substantially from small startups, to large public corporations, to new housing developments, to the management of large infrastructure projects such as airports and toll roads. The element they have in common is that these investments could not have been financed through traditional sources of financing because they require a highly motivated investor who has substantial control rights to make them profitable. Private equity funds provide institutional investors a way to gain exposure to sectors of the economy that they could not without these funds, and consequently add to the diversification of a broad portfolio. 
Private equity funds generally have a ten-year stated life and are sometimes extended beyond that point. When the fund exits its investments in its portfolio companies, the funds receive capital that they return to their investors. Because of this structure, private equity funds cannot return capital to investors until they exit their portfolio investments, and funds' managers' control over this timing is quite limited. For this reason, most funds are set up in a closed-end structure, in which investors in the funds cannot sell their shares back to the fund, and must wait for the fund to liquidate its portfolio companies before receiving capital back from the fund. ${ }^{3}$

Because it takes so long to receive capital back, investors in private equity funds, typically large institutional investors, generally do not invest in private equity funds unless they expect to be able to keep their capital in the fund for full life of the fund. However, unforeseen circumstances sometimes do occur, and can cause investors to desire to exit their investments early. Exiting early through the secondary market allows investors both to receive back some of the capital they have already invested, and also to be relieved of the obligation to provide capital for the fund's subsequent investments.

\subsection{Why Investors Transact in the Secondary Market}

Industry professionals suggest that there are a number of reasons why LPs choose to sell their positions prior to the end of the fund's life. The most common motivations for investors to sell a position include a set of reasons best characterized as active portfolio management. These include the desire of investors to concentrate their investments into a smaller set of managers, resulting in the sale of positions deemed to be outside of the core set of fund managers. During our sample period the industry also went through important broad strategy shifts that brought many investors to sell their private equity holdings, including efforts to 'manage down' their private equity relationships. We also observe in our data cases where LPs change the type of their fund investment, for example, from energy funds to mid-market buyout funds or funds that would accommodate direct investment along with traditional private equity investments.

\footnotetext{
${ }^{3}$ A few funds are open-end, and do allow investors to receive capital back from the fund at specified points in time. These are typically funds that invest in long-lived assets such as infrastructure, which require a very long commitment from the fund (typically 50 years or more).
} 
Investors sometimes choose to sell for other reasons outside of active portfolio management. Unexpected cash flow demands such as those occurring during the 2008-2009 financial crisis can lead investors to desire liquidity. In addition, some investors have restrictions on their portfolio composition and can become overweighted in private equity following declines in the public markets, given that public market securities are marked to market in real time. Finally, regulatory changes such as Solvency II, Basel III, and the Volcker rule led some investors to reduce their private equity holdings.

While there is no way to know for sure why a particular LP wishes to sell his position, the age of the fund at the time of the sale provides some indication about the reason. In private conversations, industry practitioners generally claim that portfolio rebalancing-motivated sells occur most frequently when funds are between the ages of 4 and 9 years old. Transactions of funds in this age group represent the majority of the transactions in our sample.

The second most common type of transaction in our sample is what practitioners refer to as a "tailend sale." These transactions occur when their positions in funds are near the end of their lifecycle and when the typical fund contains only a small number of unliquidated portfolio companies. Often the LP will have a target rate of return for his private equity investment and will sell his position if he finds that he can achieve this rate of return through a sale.

Finally, there are some transactions that occur early in a fund's life. These transactions tend to occur because of liquidity shocks, or because of regulatory requirements.

Buyers in the secondary market tend to be relatively sophisticated investors that have developed expertise in evaluating private equity portfolios, and hope to earn returns from providing liquidity in the secondary market. Some are institutional investors such as public retirement systems, but the most common buyers are funds of funds that are set up for the explicit purpose of investing in the secondary market. ${ }^{4}$ An example of a large player in this market is the Blackstone Group, which has raised over $\$ 14$ billion in a number of different secondary funds-of-funds. The returns to these secondary funds are generated both by

\footnotetext{
${ }^{4}$ See Guide to the Secondary Market, published by Dow Jones in 2014, for a list of these funds, as well as the identity of other buyers in the secondary market.
} 
the returns on the underlying private equity funds and also by the funds being acquired at a discount (or premium) to their fundamental value.

\subsection{How the Market is Structured}

Because of the demand from potential sellers and buyers, around 2001, some intermediaries started making a market in secondary stakes of private equity funds. ${ }^{5}$ These intermediaries assist LPs in marketing their stakes in private equity funds to potential buyers. In a typical transaction, a potential seller engages an intermediary, who pays them a fee, typically about $1 \%$ of the value of the stake. The intermediary locates potential buyers, gets approval from GPs for potential buyers to purchase the stake, ${ }^{6}$ distributes information about the fund's portfolio companies to these counter-parties, accepts offers for the seller's stake in a private equity fund, and assists with the sale of the stake to the counter-party. The buyer pays the purchase price for the fund's existing investments to the seller (expressed as a percentage of NAV), takes on the seller's obligations for any committed future investments to the fund, and receives any distributions from the fund tied to that position.

Individual funds are frequently sold as part of a larger portfolio transaction. In a portfolio transaction the buyer submits an offer price for an entire portfolio of funds. As the transaction date approaches, the buyer and seller negotiate prices of the individual funds in the portfolio subject to the constraint that the size-weighted average of the individual prices equals the winning offer price. ${ }^{7}$

Figure 1 presents statistics on the size of the secondary market through time. This figure documents that the market has grown dramatically, from $\$ 2$ b in 2001 to $\$ 42 b$ in 2014 . There was an increase in volume around the time of the 2008-2009 financial crisis, presumably because endowments and pension funds

\footnotetext{
${ }^{5} \mathrm{~A}$ few funds dedicated to seasoned private equity purchases, particularly at the tail end of funds lives, existed as early as the 1990s but their direct investments were not brokered through an intermediary.

${ }^{6}$ Most partnership agreements do not allow limited partners to sell their stakes to whomever they want without having approval of the GP. For this reason, intermediaries must get approval from GPs before allowing potential new investors to bid. GPs will usually grant such approval for most potential new LPs, since having more liquid stakes makes their fund more desirable to future investors, though industry professionals indicate a handful of GPs can be quite selective about new LPs.

${ }^{7}$ In the empirical work below, we consider the extent to which the results are affected by the inclusion of portfolio transactions. In general, the results for the portfolio transactions in our sample are similar to the ones for individual deals.
} 
worked to lower their exposure to private equity. Subsequent to the financial crisis, volume has continued to increase. Even the $\$ 42 \mathrm{~b}$ volume in 2014 represents a small fraction of total private equity commitments, so it is likely that the secondary market volume will continue to grow in the future.

\subsection{The Cost of Transacting}

Stakes in private equity funds are long-term investments for which there are few potential buyers, and restrictions that further limit the possible buyers. ${ }^{8}$ In addition, because the fund's portfolio companies are usually private, there are no available market values, and publicly available information about these companies is limited. GPs do have considerable information about the portfolio companies, some of which they release to their own LPs, but not to the general public. Subject to non-disclosure agreements, intermediaries share the "hard" information that can be distributed to potential new LPs and facilitate communication between potential buyers and GPs for the purposes of communicating additional "soft" information about funds. While potential buyers do their best to resolve information asymmetries, uncertainty about the quality of a fund's underlying investments takes time to resolve. For this reason, and because of thinness in the market in terms of potential buyers, the cost of transacting in any secondary market for stakes in private equity companies is likely to be high. ${ }^{9}$

How can one measure the transactions cost in the secondary market for private equity stakes? Part of the cost is a fee that is paid to the intermediary from the seller. However, the more important part of the transaction cost in this market is the discount a seller must pay to compensate for the illiquidity in the market. ${ }^{10}$ Conceptually, this discount is the price that a buyer pays relative to the market assessment of the asset's fundamental value. Analogously, in an IPO or SEO, the transaction cost paid by the issuer includes both the fees to the underwriter and the underpricing of the issue. Importantly, the secondary market for

\footnotetext{
${ }^{8}$ In 2003, when the University of Michigan provided performance data to a newspaper, Sequoia Capital announced that they would refuse to accept capital from the University of Michigan. More recently, in 2014 KKR threatened to cut off the Iowa Public Pension Fund from future investments if they complied with a public records request about the fees that they paid KKR. See Wall Street Journal, Nov. 4, 2014. These examples, however, are exceptions, and most GPs find fundraising sufficiently difficult that they do not limit the investors who could become future LPs.

${ }^{9}$ Kyle (1985) and Glosten and Milgrom (1985) present classic models in which the cost of transacting arises endogenously as a function of asymmetric information and other factors.

${ }^{10}$ We assume that the transactions costs are paid by the seller, since the seller imitates contact with the intermediary for assistance in selling their holding. In practice, the seller is generally the one who pays the intermediary's fees.
} 
private equity stakes differs from the sale of public securities because there is not a clear market-based assessment of the stake's true value.

Practitioners typically use NAV as a measure of the fund's fundamental value, since NAV is the measure of the fund's value that is reported to the fund's investors. However, there is substantial discretion involved in computing NAV, and a natural question is whether NAVs fairly represent the present value of the fund's future cash flows. Recent empirical work suggests that because NAVs are based on historical cost, they do not adjust fully for value changes, so NAVs tend to understate the value of the portfolio companies. In addition, there is some evidence that some GPs tend to boost a fund's NAV when they are raising subsequent funds, and also near the end of the fund's life, when doing so can lead to higher fees. (See Brown et al., 2014; Jenkinson et al., 2014, and Barber and Yasuda, 2015)

It is important to remember that the purchase price of the stake, and consequently any discount to NAV, only applies to the drawn down portion of the commitment. The liability to participate in future drawdowns also changes hands when the stake is sold, and these future drawdowns are not affected by the purchase price of the secondary market transaction. Discounts to NAV can be misleading for this reason; if an LP has a stake in a fund and wishes to relieve himself of future liabilities, he could be willing to pay a seemingly high price to do so. For example, if a fund has only drawn down 5\% of its commitments, an LP who sells a stake at a $50 \%$ discount is really only paying $2.5 \%$ of his total commitment to avoid future drawdowns (assuming the NAV of the invested assets is close to historical cost). While the 50\% discount could sound like a large price to pay to sell the stake, relative to the entire commitment, it could be a relatively low price to pay if relieving himself of the liability it is valuable to the LP.

Interpreting discounts from NAV as a measure of liquidity costs in the secondary market is a common industry practice. However, NAV can be a misleading measure of fundamental value because of the way it is measured and the GP's ability to manipulate it. For this reason we also compute returns to buyers and sellers based on the price at which the secondary sale takes place as well as data on the cash drawdowns and distributions a fund makes. To the extent that buyers earn higher returns than sellers 
actually received, or would have received if they held the fund to maturity, these differences in returns are additional measures of the liquidity costs borne by sellers who transact in the secondary market.

\section{Sample of Secondary Market Transactions}

\subsection{Sample Selection}

Our data on secondary market transactions are provided by a large intermediary in the private equity secondary market. This firm's market share in brokering LP liquidity has varied through time, but peaks in the later years of our sample. Our data on secondary market prices runs from 2006 to 2014. While the private equity secondary market has existed since 2001, only \$23B in transactions occurred between 20012005, compared to $\$ 200 B$ in the years 2006-2014 (See Figure 1). In our sample period of 2006-2014, about $90 \%$ of all secondary market transactions have occurred.

Our database contains information on both bids and transaction prices for stakes marketed by the broker, the total value of the transactions, as well as other information specific to each transaction. For some transactions, including all in the 2006-2009 period, we do not have bid data but do have transaction data.

We match the transaction data with data on cash flows and returns from Preqin. Preqin constructs two databases on which we rely heavily: the first contains returns for virtually all private equity funds, and the second contains cash flows on the drawdowns from limited partners and the distributions to the limited partners. These cash flows are aggregated at a quarterly level, so that, for example, if a fund had two drawdowns in one quarter, the Preqin database would report their sum for that quarter. Unfortunately, the Preqin cash flow database does not cover the universe of private equity funds, so that our sample size declines whenever we rely on it.

To calculate returns to buyers and sellers in the secondary market, we merge the transaction database with one or both of the Preqin databases. The merge begins with 2,440 completed transactions. Implementing a screen within the transaction data for obvious outliers where the percent of NAV paid for a transaction seems implausible (\% of NAV $<25 \%$ and $>400 \%$, or other obvious data errors on transaction 
price) reduces the sample to 2,226 transactions. Our returns calculations require one transaction value per fund quarter, so in circumstances in which a fund transacted multiple times in a quarter, we calculate the average percent of NAV paid for a fund in a given quarter. Merging observations in which funds transacted multiple times within particular quarters reduces the sample to 1,998 fund quarter transactions. When we restrict the sample to those funds for which cash flows are available from the Preqin cash flow database, it further declines to 1,054 fund quarter transactions.

One concern with computing returns to secondary market investments is the possibility that a secondary market buyer can purchase a fund at a discount to NAV in one quarter and then mark the value of the fund to NAV in the subsequent quarters, generating a mechanically large "paper" return. Because of this concern, we remove observations where a transaction took place within 4 quarters of the fund liquidation or last available NAV. ${ }^{11}$ This additional restriction reduces the sample to 811 fund quarter observations. We remove an additional 13 observations with reported annualized IRRs greater than 200\% because they do not appear representative of the full sample and are likely driven by misreported cash flow data in Preqin. Finally, to be included in our final sample we require that each transaction is for a fund that has sufficient data to calculate returns to both buyers and sellers. The resulting sample is 700 fund quarter transactions from 388 unique funds. Of the 388 unique funds represented in the final sample, 220 are buyout funds, 122 are venture capital funds, while the remaining 46 are real estate, funds of funds or "other" fund types. $^{12}$

\subsection{Sample Characteristics}

Panel A of Table 1 reports the discounts to NAV for bid and transaction prices, with funds grouped into buyout, venture, fund of funds, and real estate, with all other funds combined together in a fifth

\footnotetext{
${ }^{11}$ In a previous draft, we have presented the results without imposing this requirement on our sample. The pattern is similar to that reported here except that buyers average returns are even higher, since some observations are mechanically marked up shortly after the purchase.

${ }^{12}$ For calculations that do not require returns data, such as those presented in Tables 1 and 2, we include all funds in the transactions database, so these tables contain a substantially larger number of observations. Total transaction counts in Tables 1a and 1b differ from those in Table 1c because of missing data on fund size for some transactions.
} 
category. ${ }^{13}$ This table indicates that both the bid and transaction prices generally occur at a discount to NAV. For the full sample, the average and median transaction prices are $86.2 \%$ and $85.6 \%$ of NAV respectively. The most commonly transacted type of fund is a buyout fund, with 2,303 bids and 1,137 transactions and the next most common is venture with 603 bids and 705 transactions. ${ }^{14}$

Panel B of Table 1 documents the number and price of bids and transactions in our sample by year. The number of transactions remains roughly constant over time (between 200 and 300 per year). Since the overall market has grown dramatically over our sample period, the additional transactions not in our sample reflect entry by new intermediaries. Our bid data begins in 2010 and for the years in which we have bid data, there are roughly 3 bids for each transaction. After 2006, deals tended to occur at a discount to NAV, with an average and median bid and transaction price less than NAV. The one outlier is 2009, when prices were noticeably lower than in other years, with a mean transaction price of just $54 \%$ of NAV and a median of $52 \%$ of NAV. During this year, the financial crisis created a demand for exits of private equity positions established during the prior boom years. The volume of transactions (213), however, was not particularly high relative to other years, suggesting that there was a shortage of potential buyers at this time, so that the only exits that did occur were at even deeper than usual discounts.

Panel $\mathrm{C}$ of Table 1 documents the fund size and transaction size, both expressed in dollars and also as a fraction of fund size. The funds for which there are secondary transactions tend to be relatively large compared to the Preqin universe of funds. The buyout funds that are transacted have a mean AUM of $\$ 3.7$ billion (median $\$ 1.8 \mathrm{~B}$ ), the venture funds have a mean AUM of $\$ 459 \mathrm{~m}$ (median $\$ 365 \mathrm{~m}$ ), and the remaining funds have a mean AUM of \$1.3 B (median \$730m). In comparison, the overall Preqin sample has a mean AUM of $\$ 1.7$ billion for buyout funds and mean AUMs of $\$ 380$ and $\$ 995$ million for venture and remaining funds. For transactions to have a robust secondary market, there has to be sufficient demand and information available for the fund, which tends to occur only for very large funds. Investments in large

\footnotetext{
${ }^{13}$ Funds in this "other" category include funds specializing distressed debt, energy, infrastructure, natural resources, restructuring, special situations, as well as an "other" category defined by the broker.

${ }^{14}$ The number of transactions can exceed the number of bids in Table 1 (e.g. venture funds) because we are missing bid data for the 2006-2009 portion of the sample.
} 
funds appear to be more liquid than investments in smaller ones: there are more transactions for the larger funds and they occur at a smaller discount to NAV.

To assess the representativeness of funds transacted on the secondary market, Panel A of Table 2 tabulates summary statistics for the Preqin universe while Panel B tabulates the same statistics for our main sample. Funds represented in the transaction data are larger on average than funds in the Preqin universe. Average AUM for buyout funds in the merged sample average \$3.2B, compared to only \$1.6B AUM for average buyout funds in Preqin. Venture and "other" fund types are also larger, on average, in the merged sample. Table 2 also indicates that buyout funds in the merged sample have slightly higher IRRs, on average, than the Preqin universe. Venture and "other" fund types have very similar IRRs in each of the two samples.

Table 3 presents statistics on sales by the age of the fund at the time of the sale. In Panels A-C, we group the transactions into multiple age categories: 0-3 years, 4-9 years, and at least 10 years. Funds generally have a stated life of ten years, but with extensions can live as long as 15 years, with most of the investment occurring during the first few years. Funds generally expect to exit their investments by year 10 , although they often exercise an option to extend the fund's life by multiple years at the GP's discretion and with the permission of their LPs. Consequently, transactions in the "at least 10 years" category are tail end transactions of funds that have exited the majority of their investments but still have a few left on their books.

Transactions occurring between years 4 and 9 are most common, with 704 transactions, which is $59 \%$ of the 1186 transactions for which we have cash flow data and can compute NAV. There is also a surprisingly large number of tail end transactions, 354 , which is $30 \%$ of the sample. Transactions that occur early or late in a funds life tend to be at lower prices than other transactions. Late in a fund's life, if the fund has already provided a return that clears the fund's hurdle rate but still has a few investments left, LPs will sometimes sell the fund in the secondary market to "clean up" their books. Early in a fund's life, the larger discounts could reflect higher uncertainty about GP quality as well as the value in relieving the LP of larger and longer-lasting future drawdown obligations. 
In Panel D of Table 3 we report the average fund age at time of transaction for each year of our sample. The data reveal some notable patterns. Funds sold in 2009 had an average (median) age of 19.5 (14) quarters. In contrast, funds sold in the 2010-2014 period tended to be much older with the mean (median) age peaking at 40.2 (35) quarters for transactions in 2013. These data suggest that LPs desiring liquidity in 2009 were more likely to sell younger funds. In contrast, older funds were more likely to be sold later in the sample period when liquidity demands were not likely to have been the primary reason for selling.

Table 4 presents probit regressions that characterize the attributes of funds in the Preqin universe that appear in the transaction sample. The results suggest that both buyouts and venture funds transact more frequently than "other" funds (the omitted category). Larger firms are much more likely to be transacted than smaller funds, presumably since there is much more information available about larger funds and more potential buyers who already own a stake in the fund, so have acquired the necessary information on it. As suggested by the results in Table 3, young funds are less likely to transact than older funds. These results suggest that the secondary market is most liquid for larger funds that have been in existence for a few years. Finally, models (2) and (3), which include quarter fixed effects, indicate that funds that higher performing funds, as measured by their PME, are less likely to transact.

\section{The Returns of Sellers and Buyers}

\subsection{Internal Rates of Return}

In Table 5 we present the annualized IRRs that buyers and sellers receive using the merged transaction, Preqin sample. Using the cash flow data from Preqin and the purchase price in the secondary market, we calculate the IRR that each buyer and seller receives on his investment. The first two columns of Panel A of Table 4 document that the average return to sellers was $1.3 \%$ while the average return to buyers was $22.3 \%$. The difference between these average returns, reported in Column 3, is $21.0 \%$, which 
is statistically significantly different from zero. ${ }^{15} \mathrm{We}$ also report the median IRRs for sellers and buyers; these values are $3.3 \%$ for sellers and $16.7 \%$ for buyers averaging across all funds. For the median transaction, buyers outperform sellers but the differences are not as large as for the average IRR. In a typical transaction, sellers receive a positive return of about $3.3 \%$ and buyers receive between $16.7 \%$ and $22.3 \% .^{16}$

The remaining columns of Table 5 break down the buyer and seller IRRs by the age of the fund at the time of the transaction. The results presented document stark differences in seller returns for funds of different ages. Sellers of young funds take substantial losses, with an average IRR of $-30 \%$. This very low IRR could reflect that a large fraction (49 of 92) of the sales of young funds occurred at large discounts during the 2008-2009 financial crisis. In transactions of funds between 4 and 9 years old, which constitute the majority of our sample, sellers receive a small gain, with an IRR of $2.1 \%$, and in tail end transactions, sellers average a $16.5 \%$ IRR. Buyers, on the other hand, do reasonably well in all transactions, with an average IRR of at least $20 \%$ for each age group.

In Panels B, C, and D we repeat this analysis for buyers and sellers of each type of fund separately. In each case, the average buyer IRR is substantially higher than the average seller IRR. For example, the results in Panel B document that for buyout funds, the average IRR for buying institutions was $23.7 \%$, compared to roughly $1.0 \%$ for selling institutions. The differences between seller and buyer for venture (Panel C) and other funds (Panel D) are similar to those for buyouts. For each type of fund, buyers receive higher IRRs than sellers; sellers appear to be willing to take a haircut so that they can be relieved of their obligation for future commitments.

\footnotetext{
${ }^{15}$ Our statistical tests of the differences between buyer and seller returns clusters standard errors by quarter of transaction fixed effects.

${ }^{16}$ Alternatively, one could weight the transactions by the value of the transaction. Using this approach gives similar results to those reported in Table 4. However, there are some extremely large transactions in our sample that make this calculation potentially unrepresentative; the maximum transaction is for a stake with a NAV of $\$ 325 \mathrm{~m}$, while the median transaction is for only $\$ 4.6 \mathrm{~m}$.
} 


\subsection{Public Market Equivalents}

A potentially important consideration in interpreting the IRRs of buyers and sellers is the performance of the equity market during different portions of our sample period. In particular, the earlier part of our sample includes the 2008-2009 financial crisis, while the later part of our sample includes the 2010-2014 period in which the equity market performed very well. Since buyers held their positions later in time than sellers, it is possible that the observed differences in IRRs between buyers and sellers could reflect this timing rather than transactions costs in the secondary market.

To evaluate the extent to which the changing market conditions can explain the differential performance between buyers and sellers, we calculate the "Public Market Equivalent (PME)", which compares private equity performance relative to the benchmark of public equity markets, and is often considered to be the preferred way to evaluate private equity performance (see Kaplan and Schoar (2005) and Korteweg and Nagel (2016)). The PME is formed by taking the ratio of discounted distributions (from the fund to investors) to discounted capital calls (capital provided by investors to the fund), using the realized return on the public equity market as the discount rate. A PME of greater than one indicates that a fund has outperformed the public equity market.

The PME does not adjust for the time a fund holds its assets, which is not an issue for prior studies such as Kaplan and Schoar (2005) that compare the performance of funds over their entire lives. However, the comparisons in our study are over very different time horizons. For example, we present returns for buyers and sellers of young funds, for which the buyer owns the fund for a much longer time than the seller and for tail end funds, for which the seller owns the fund for a much longer period than the buyer. For this reason, we focus our discussion on annualized PMEs, which are just PMEs taken to the power of one divided by the number of years a seller or buyer holds the asset.

Table 6 presents the annualized PMEs for buyers and sellers in our sample. Panel A of Table 6 documents that for the overall sample, sellers have an average annualized PME of .974 and buyers of 1.023. These average annualized PMEs imply that sellers underperform the public equity market by $2.6 \%$ per year while buyers outperform it $2.3 \%$ per year. Buyers, therefore, outperform sellers by about 5 percentage 
points per year. The difference between these returns is statistically significantly different from zero. Median annualized PMEs are closer to 1, .99 for sellers and 1.01 for buyers, indicating that the median performance is very close to that of the public equity market.

The remaining columns of Table 6 break down the annualized PMEs by the fund age at the time of transaction. As with the IRR results, the seller annualized PMEs for young funds is poor, suggesting that sellers earn $85.4 \%$ per year of what they would have earned in the public equity market. Sellers who sell between year 4 and year 9 of the fund's life earn $98.3 \%$ per year of the public equity market return while sellers who hold until year 10 earn $1.7 \%$ more each year than the public market. For each of these groups, the buyers earn more than the public equity market although in the tail end sales, their annualized return is lower (albeit not significantly) than the sellers.

Panels B, C, and D present the PME calculations for each type of fund separately. The numbers indicate that for each type, buyers have an annualized PME that is between 4 and 5 percentage points higher than sellers. Breaking down each type of fund by age of fund, the differences between buyer and seller annual returns are very large (about 25 percentage points per year) for the transactions of young funds, about 3 percentage points per year for the typical transaction in our sample that occurs for a fund between 4 and 9 years old, and close to zero for the tail end funds. These differences are generally statistically significant but smaller in magnitude than the differences in IRRs reported in Table 5. They suggest that part but not all of the spread differences in IRRs reported in Table 4 occur because of time series variation in market-wide returns.

Nonetheless, except for sales of tail end portfolios, regardless of the type of fund or the approach used to measure returns, buyers in the secondary market outperform sellers. Moreover, these calculations do not include the fees paid to the intermediary, which are usually about $1 \%$ and are paid by the seller. Including these fees would make the differences in returns between buyers and sellers even larger. These differences in returns between buyers and sellers are consistent with the view that the transactions occur when sellers have a strong incentive to sell, so are willing to pay a cost to relieve themselves of their some of their commitments to private equity. 


\section{Cross-Sectional Variation in Transactions Costs}

Funds-of-funds that are created to invest in secondaries often state that they achieve returns by providing liquidity to private equity investors. The evidence that buyers outperform sellers is consistent with the observation that they are able to purchase their stakes at a discount to the stakes' underlying value. We can view this difference in returns as reflective of the transactions costs in this market, and the magnitude of this outperformance suggests that these transactions costs are meaningful.

Theories of market microstructure suggest that there are two main factors that determine the magnitude of transactions costs in any market: the overall demand for an asset (the "thinness" of the market) and the asymmetric information between buyers and sellers (see Glosten and Milgrom (1985) and Kyle (1995)). We next examine whether these proxies for these factors appear to affect the transactions costs in the secondary market for private equity stakes.

We use two measures of transactions costs in our analysis. First, we consider the price as a percentage of NAV paid in a given transaction. This measure has the advantage of being easy to measure and commonly used by practitioners. However, as discussed before, the NAV is an accounting measure that can deviate substantially from the market's assessment of the value of fund's invested assets. For this reason, as a second measure of transactions costs, we use the difference between each transaction's buyer and seller returns, measuring these returns by both IRRs and annualized PMEs. These differences reflect the returns that the buyer receives for providing liquidity to the seller.

Table 7 presents estimates of equations that characterize the factors affecting the magnitude of discounts from NAV, our first measure of transactions costs. Column 1 contains estimates of the extent to which transactions costs are related to fund type and age. Column 2 includes variables reflecting overall market conditions, as measured by the average price to earnings ratio in the equity market, as well as a number of transaction-specific controls. Column 3 replaces the macroeconomic controls with quarterspecific fixed effects. Column 4 includes a fund's PME as of the time of the transaction as an additional variable. Finally, Columns 5-7 estimate the specification from Column 3 for each age group separately.

The main implications of these estimated equations are as follows. 
First, transactions costs appear to be countercyclical since they are higher when the market wide price to earnings ratio is low, which tends to be the case during recessions. The estimates in Table 7 indicate that the price to earnings ratio is positively associated with the prices paid relative to NAV. During poor economic times, capital is more constrained, so there is less capital available to purchase stakes in private equity funds. Consequently, when the economy is doing poorly, as reflected in low p/e ratios, prices tend to be lower relative to the stake's value, and returns to buyers therefore higher. In addition, there are likely to be more investors wishing to sell their stakes, which also leads to lower prices and higher buyer returns. Both of these effects likely contributed to the very low prices paid in 2009 during the financial crisis and the high returns to buyers of stakes at these low prices.

Second, transactions costs tend to be lower for larger transactions and for larger funds. There are likely to be fixed costs for an acquirer in acquiring information for a transaction, so they are willing to pay a higher price if they are acquiring a larger stake in the fund. In addition, for smaller funds, there are fewer investors familiar with the deals that the fund has made, so asymmetric information is likely to be higher than for larger funds. Finally, there are likely to be more buyers interested in purchasing a stake in a large fund than a small one, which will tend to drive down transactions costs for large funds.

Third, younger funds tend to be associated with larger transactions costs. The estimates reported in column 1 suggest that funds that are younger than 3 years trade at a much larger discount than other funds. However, this discount disappears when we control for macroeconomic factors, suggesting that the large discount for young funds is driven by the fact that investors only are likely to sell young funds during poor financial conditions, which in our sample means during the financial crisis, especially 2009.

Fourth, consistent with the unconditional tabulations presented in Table 3, the oldest funds in the sample, those sold when they are 10 years old or older, sell at a discount of about $10 \%$. This result holds even when controlling for time fixed effects, indicating that the tail-end discount is a sample-wide phenomenon that persists independent of aggregate market conditions. 
Fifth, funds that have performed better up to the time of the transaction sell at higher prices. Funds with one-standard deviation higher PMEs at the time of transaction (about 50 basis points) are associated with $2.5 \%$ higher prices as a percent of NAV.

Finally, the results indicate that transactions that occurred as part of a portfolio of transactions do not occur at significantly different prices when controlling for time fixed effects (models (3) and (4)). This result suggests that our main set of results is not being driven by cases in which LPs sell an entire portfolio of holdings at one time.

In Table 8 we present estimates of equations similar to those presented in Table 7 using the difference in returns between buyer and sellers as the dependent variable. In Columns 1-3, we measure the difference in returns using the difference in IRRs between buyers and sellers and in Columns 4-6 we use the difference in annualized PMEs between buyers and sellers. The cross-sectional patterns implied about transactions costs from the analysis of discounts to NAV in Table 7 continue to hold in the return differences presented in Table 8. Consistent with the idea that larger transactions sell at higher prices, the difference between buyer and seller returns is smaller for larger transactions. In addition, buyers earn larger returns relative to sellers on younger funds, presumably because they sell for lower prices.

Interestingly, when differences between buyer and seller returns are measured using PMEs, the results indicate that sellers of funds greater than ten years old earn larger returns than buyers, despite the fact that these transactions occur at large discounts to NAVs. This result suggests that a fund's most profitable exits occur before these transactions. In contrasts, the assets left after year ten are lower quality and buyers require large discounts to NAV to generate acceptable returns.

Overall, there is a consistent cross-sectional pattern in the transaction prices (Table 7) and differences between buyer and seller returns (Table 8). Both sets of results suggest that transactions costs in the secondary market for private equity being affected by information asymmetries and the overall thinness in the market for stakes. Theories of market microstructure that have been tested extensively on public capital markets appear to apply to this market as well. 


\section{Characteristics of Sellers and Buyers}

The results presented to this point are consistent with the view that the secondary market is one in which buyers provide liquidity for sellers who wish to exit their investments and receive a return for doing so. Another question concerns the identities of the buyers and sellers. If cash flow considerations affect the desire to sell, then sellers should be institutions that rely on their investments for cash flows such as endowments or pension funds, while the buyers should be investors with sufficient flexibility to take advantage of market opportunities, such as funds of funds. We now examine whether this pattern characterizes the transactions in our sample.

Table 9 documents the frequency of funds-of-funds versus other types investors as buyer or seller. This table clearly indicates that funds-of-funds are much more likely to be buyers than sellers. Funds-offunds are buyers in $85.4 \%$ of the transactions in our sample, while other investors are buyers in only $14.6 \%$. In contrast, the majority of the sellers (66.6\%) are LPs other than funds-of-funds. Table 9 also presents results broken down by type of fund (buyout, venture capital, other). This pattern suggests this market is a seller initiated market where sellers, for strategic reasons, liquidity needs, or regulatory pressure, seek to rebalance their portfolios. In contrast, buyers, primarily funds-of-funds, take advantage of their flexibility to provide liquidity to sellers and thereby earn higher returns.

Table 9 indicates that funds-of-funds are the largest providers of liquidity in the secondary market. In Table 10 we characterize the types of transactions where funds-of-funds are providing the most liquidity by tabulating the selling and purchasing patterns of funds-of-funds and other investors by the age of the fund. These patterns indicate that funds-of-funds provide liquidity to sellers across funds of all ages, but that they are the most frequent providers of liquidity for tail-end transactions. The ratio of fund-of-funds buyers to other buyers in funds 0-3 years old is 3-to-1, compared to similar ratios of 5-to-1 in middle aged funds, and greater than 10-to-1 for tail-end transactions. 


\section{Institutional Considerations}

The results presented thus far represent aggregate patterns from a set of transactions that took place in a large, sophisticated market. In this section, we discuss a number of institutional features of the market that should be considered when interpreting our results.

Portfolio vs non-portfolio bids. As discussed in Section 2.3, many transactions in our sample are traded as part of a portfolio transaction. Portfolio transactions call into question the information content of the individual transactions used to calculate returns. We re-estimate the difference between buyer and seller returns (Table 5) for a set of funds that were not sold as part of a portfolio and compare them to results for portfolio transactions. The results are qualitatively similar, though there is a slightly larger difference between buyer and seller returns for non-portfolio transactions. We also note that we control for portfolio transactions in the regression results presented in Table 7.

Pricing dates. Another institutional feature that could influence our results is the timing of the NAVs used to calculate purchase prices. Because NAVs are reported with a lag, when investors bid on funds they are often making bids based on 1 to 2 quarter old NAVs. Given that NAVs usually appreciate through time, investors could appear to offer a price at a larger discount to NAV than they actually did because we calculate the discount relative to a stale NAV. NAVs are reported quarterly, so the "staleness" of the NAV relative to the transacted price depends on the timing of the transaction relative to the timing of the reporting of new NAVs. Closely related to the stale NAV issue is the introduction of FASB 157 in 2007-2008, which changed NAV valuation practices and had the effect of making quarter-to-quarter changes in NAV more volatile. The inter-quarter volatility of NAVs due to FASB 157 has the potential to exacerbate the stale NAV issue during the majority of our sample period.

Vintage Effects. In unreported regressions we control for vintage effects for the set of regression models presented in Table 7. We find that vintage effects do not meaningfully alter the results presented in Table 7. Deal vintage is of primary importance to market participants. Fund's returns are often negatively correlated with fundraising because periods of aggressive fundraising result in large pools of capital chasing a relatively fixed set of opportunities. For this reason, fundraising also drives secondary market inventory. 
As an example, mega buyout funds raised massive amounts of capital in 2006 that was deployed at aggressive valuations over the next year. Not surprisingly, many of the funds placed on the secondary market between 2011 and 2014 were managers allocating their portfolios away from mega buyout funds. Vintage fixed effects soak up this type of variation in market pricing, but we make special note of the economics driving the need for the vintage fixed effects. Closely related to vintage effects is the timing of our sample, 2006-2014. For example, the financial crisis of 2008-2009 represents a unique episode for all financial markets and the secondary market is no exception. Secondary market purchasers, in particular, cite 2009 as a period of unique opportunity where young funds, poised for strong growth through the heart of the $\mathrm{J}$ curve, were sold at deep discounts. We note that our core set of results are robust to the removal of crisis transactions. More generally, we emphasize that all the results presented in our analysis represent those from a small and somewhat unique sample period.

Asymmetric information. In Section 5 we briefly discuss the nature of asymmetric information in the secondary market. Investors in funds are likely to hold private information about their investments. In contrast, participants in this market sometimes argue that information asymmetries tend to go the other way, with purchasers having more information about funds than sellers. This information advantage can occur because the most common type of secondary market purchaser, a fund-of-funds specializing in secondaries, specializes in acquiring information about private equity funds, especially those funds in which they have decided to invest. In contrast, sellers potentially know less about the portfolio firms of a particular fund since they are invested in many different assets and are responsible for all of them.

\section{Summary and Discussion}

Private equity funds raise capital from limited partners, invest it in portfolio companies, and return capital to the limited partners only after the fund exits its investments in the portfolio companies. Because of this structure, investments in private equity funds are relatively illiquid, and this illiquidity can be a substantial cost of investing in private equity. The market response to this illiquidity of private equity investments was to form a secondary market in which investors can trade those stakes. Using data provided 
by a leading intermediary in this market, this paper evaluates the magnitude of transactions costs in this market and consequently the extent to which this secondary market alleviates the illiquidity of private equity investments.

Investors have a desire to exit their private equity positions for a variety of reasons: to reduce their liability for future draw downs, to manage down their exposure to a particular manager or investment strategy, or to comply with regulatory considerations such as Solvency II, Basel III, and the Volker rule. For these reasons, sellers can pay a haircut to be relieved of the liabilities associated with a private equity fund and nonetheless be better off. Buyers, on the other hand appear to purchase assets when they are available at a sufficiently large discount to their underlying value. Consequently, the transactions costs in this market appear to be borne primarily by the sellers, not the buyers.

Our results suggest that transactions costs in the secondary market for private equity investments are reasonably large. The most common transactions in this market are for funds that have been in existence for between 4 and 9 years; for these funds the typical transaction is at a discount of 9 percent to NAV. In these transactions, buyers outperform sellers by an IRR average of $17.6 \%$, but much of this difference comes from the timing of their investments; the difference in annual performance for buyers and sellers relative to the public equity market is about $3 \%$ per year. Nonetheless, the liquidity cost of investing in this market is substantial and one that investors should take account of when considering investing in private equity.

Transactions costs appear to be relatively high, most likely because of a limited number of participants and the asymmetric information about both funds and their portfolio firms. Cross-sectionally, our results suggest that when markets are thinner, and when there is likely to be higher asymmetric information, our measures of transactions costs are higher. In particular, we find that transactions costs are higher during poor economic times, when the fund is smaller, when the stake of the fund being transacted is smaller, and when funds have lower PMEs as of the transaction date.

We also consider the characteristics of the buyers and sellers. Sellers tend to be investors such as pension funds, foundations and endowments, which rely on cash flows from their investments to fund their 
real activities. These types of investors sometimes, for a number of reasons, wish to rebalance their positions and to relieve themselves of the liability for future draw downs. In contrast, the buyers of these funds tend to be non-traditional investors without immediate cash flow requirements, who increase their returns by providing liquidity to these cash flow oriented investors. Often these investors are funds of funds that are established for the explicit purpose of taking advantage of opportunities in the secondary market.

There are a number of implications of this analysis. First, we provide insights into the workings of the secondary market for private equity investments. This market appears to be a seller initiated market in which sellers pay the transactions costs. Yet, the very existence of this market, and increased volume through time, indicates that the ability to obtain liquidity via the secondary market is valuable to sellers.

Second, the results suggest that even though investors can now sell their stakes in private equity investments, the sale of these stakes is costly. Therefore, investors should take the expected transaction cost of selling the position into account when making portfolio decisions, and limit their investments in private equity to those that are unlikely to be reversed in the future.

Third, the results imply that purchasers of stakes in private equity have done well historically, typically outperforming other investors in private equity. This strong performance has likely contributed to the growth of fund of funds specializing in acquisitions of stakes in funds through the secondary market. As this growth continues, it is possible that sellers will receive higher bids for their stakes, which would contribute to lowering transactions costs in the future and lowering the returns to future secondary funds.

Fourth, the analysis provides an approach to estimating transactions costs in markets for which it is not easy to measure the fundamentals of the asset being transacted. If the expected returns to buyers and sellers absent any transactions costs should be equal, then a comparison of the two provides a lower bound on the magnitude of these costs.

Overall, the secondary market for private equity investments has developed for the same reason as any market, because there are buyers and sellers who wish to transact. Sellers are usually private equity investors who are seeking to rebalance their portfolio. Buyers tend to be opportunistic investors who are able to acquire stakes in private equity funds at a discount. Transactions costs in this market are high for 
reasons suggested by market structure theory: it is a relatively thin market with few buyers and sellers in which asymmetric information is likely to be high. These costs tend to be inversely related to fund size, so this market is an exit option for only investments in the largest and most well known funds. Consequently, the liquidity cost of investing in private equity is high, and likely to remain an important consideration for investors when managing their private equity portfolios. 


\section{References}

Barber, Brad and Ayako Yasuda (2015) "Interim Fund Performance and Fundraising in Private Equity," Working Paper, UC Davis.

Bollen, Nicholas and Berk A. Sensoy (2015) "How much for a Haircut: Illiquidity, Secondary Markets, and the Value of Private Equity," Working Paper, Ohio State University.

Brown, Gregory W., Oleg Gredil and Steven N. Kaplan (2014) “Do Private Equity Funds Game Returns?" Working Paper, University of North Carolina.

Cavagnaro, Daniel, Sensoy, Berk A., Yingdi Wang and Michael S. Weisbach (2016) "Measuring Institutional Investors' Skill from their Investments in Private Equity," Working Paper, Ohio State University.

Glosten, Lawrence R. and Paul R. Milgrom (1985) "Bid, Ask and Transaction Prices in a Specialist Market with Heterogeneously Informed Traders," Journal of Financial Economics, 14, 71-100.

Harris, Robert, Tim Jenkinson and Steven N. Kaplan (2014) "Private Equity Performance: What do we Know?" The Journal of Finance, 69, 1851-1882.

Higson, Chris and Rudiger Stucke (2012) "The Performance of Private Equity" Working Paper, London Business School.

Jenkinson, Tim, Wayne R. Landsman, Brian Rountree, and Kazbi Soonawalla (2015), "Private Equity Net Asset Values and Future Cash Flows," Working Paper, University of Oxford.

Kaplan, Steven N. and Antoinette Schoar (2005) "Private Equity Performance, Returns, Persistence and Capital Flows," The Journal of Finance, 60, 1791-1823.

Kleymenova, Anya, Eli Talmor and Florin Vasvari (2012) "Liquidity in the Secondaries Private Market," Working Paper, London Business School.

Korteweg, Arthur and Stefan Nagel (2016) "Risk Adjusting the Returns to Venture Capital", The Journal of Finance, forthcoming.

Kyle, Albert S. (1985) “Continuous Auctions and Insider Trading,” Econometrica, 53, 1315-1336.

Lerner, Josh, Antoinette Schoar and W. Wongsunwai (2007) "Smart Institutions, Foolish Choices: The Limited Partner Performance Puzzle," The Journal of Finance, 62, 731-764.

Ljungqvist, Alexander, Matthew Richardson and Daniel Wolfenzon (2007) "The Investment Behavior of Private Equity Funds: Theory and Evidence,” Working Paper, NYU.

Longstaff, Francis (2014) "Valuing Thinly-Traded Assets,” NBER Working Paper 20589.

Petersen, Mitchell A. and Raghuram G. Rajan (1994) "The Benefits of Lending Relationships: Evidence from Small Business Data,” The Journal of Finance, 49, 3-37. 
Phalippou (2012) "Private Equity Funds Performance, Risk and Selection," in Athanassiou, Phoebus (ed.) Research Handbook on Hedge Funds, Private Equity and Alternative Investments, Edward Elgar Publishing.

Phallippou, Ludovic and Oliver Gottschalg (2009) "The Performance of Private Equity Funds," Review of Financial Studies, 22, 1747-1776.

Robinson, David T. and Berk A. Sensoy (2013) "Do Private Equity Fund Managers Earn their Fees? Compensation, Ownership and Cash Flow Performance," Review of Financial Studies, 26, 2760-2797.

Robinson, David T. and Berk A. Sensoy (2015) "Cyclicality, Performance Measurement, and Cash Flow Liquidity in Private Equity,” Journal of Financial Economics, forthcoming.

Sensoy, Berk A., Yingdi Wang and Michael S. Weisbach (2014) "Limited Partner Performance and the Maturing of the Private Equity Industry," Journal of Financial Economics, 112, 320-343.

Sorensen, Morten and Ravi Jagannathan (2015) "The Public Market Equivalent and Private Equity Performance," Financial Analysts Journal, 71, 43-50. 
Figure 1: Global secondary transaction volume ( $\$$ billion)

(Sources: Greenhill-Cogent Partners "Secondary Market Trends \& Outlook, July 2015", Capital Dynamics, July 2015)

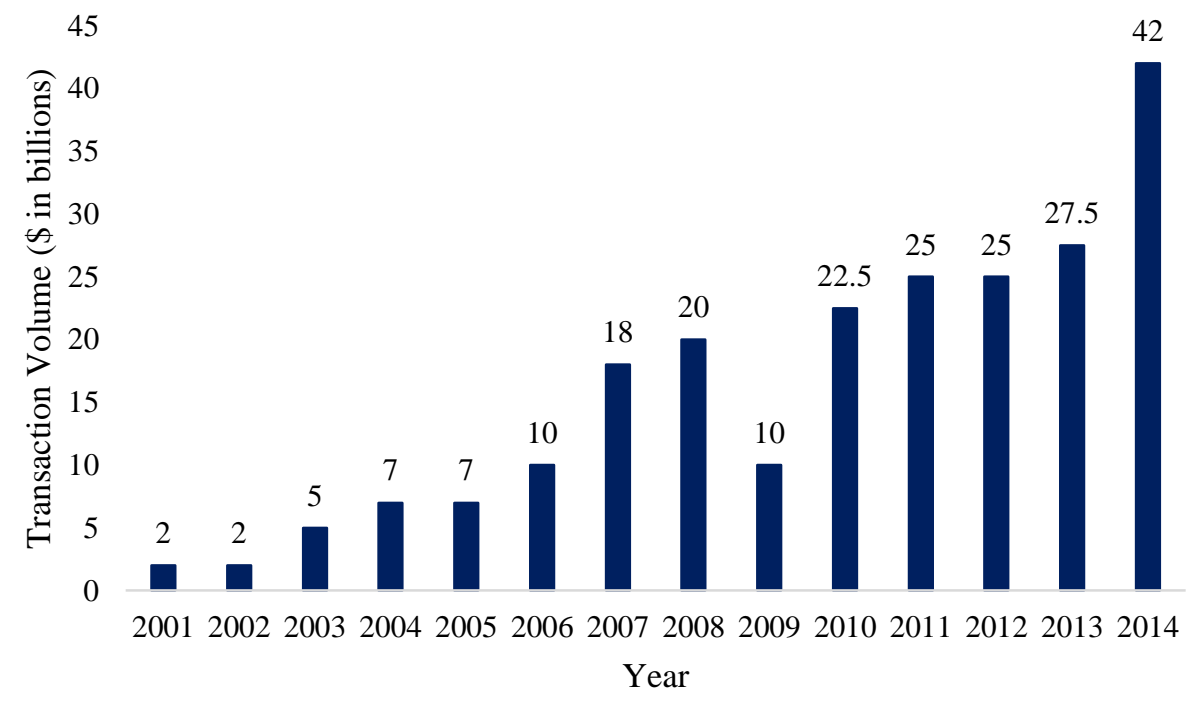


Table 1. Secondary Market Bid and Transaction Prices by Fund Type and by Year of Transaction

This table reports summary statistics on secondary market transactions by fund type (Panel $A$ ) and through time (Panel B). We report the sample size, mean, median, and standard deviation of secondary market bids and of completed secondary market transaction prices. Bids and transaction prices are reported as a percent of the Net Asset Value (NAV) of the underlying funds being transacted. Panel C reports summary statistics on fund size, transaction size, and the transaction size as a fraction of fund size. Bid data, transaction prices, fund size, and transaction size data are all reported in the transaction database.

Panel A. Secondary Market Activity by Fund Type

\begin{tabular}{|c|c|c|c|c|c|c|c|c|}
\hline & \multicolumn{4}{|c|}{ Bid Data } & \multicolumn{4}{|c|}{ Transaction Data } \\
\hline & \multicolumn{3}{|c|}{ Bid Price $\%$ NAV } & \multirow[b]{2}{*}{ SD } & \multicolumn{4}{|c|}{ Purchase Price $\%$ NAV } \\
\hline & $\mathrm{N}$ & mean & median & & $\mathrm{N}$ & mean & median & SD \\
\hline Buyout & 2303 & 0.812 & 0.810 & 0.143 & 1132 & 0.851 & 0.865 & 0.305 \\
\hline Venture & 603 & 0.691 & 0.704 & 0.121 & 704 & 0.900 & 0.856 & 0.385 \\
\hline Fund of Funds & 25 & 0.740 & 0.740 & 0.111 & 56 & 0.784 & 0.788 & 0.192 \\
\hline Real Estate & 195 & 0.807 & 0.825 & 0.083 & 77 & 0.946 & 0.937 & 0.228 \\
\hline Other & 349 & 0.815 & 0.840 & 0.132 & 257 & 0.799 & 0.808 & 0.231 \\
\hline Total & 3475 & 0.773 & 0.784 & 0.118 & 2226 & 0.862 & 0.856 & 0.323 \\
\hline
\end{tabular}

Panel B. Secondary Market Activity through Time

\begin{tabular}{ccccc} 
& \multicolumn{4}{c}{ Bid Data } \\
\cline { 2 - 5 } & \multicolumn{5}{c}{ Bid Price \% NAV } \\
Pre-2006 & N & mean & median & SD \\
\cline { 2 - 5 } 2006 & -- & -- & -- & -- \\
2007 & -- & -- & -- & -- \\
2008 & -- & -- & -- & -- \\
2009 & -- & -- & -- & -- \\
2010 & -- & -- & -- & -- \\
2011 & 717 & 0.780 & 0.786 & 0.187 \\
2012 & 778 & 0.766 & 0.780 & 0.137 \\
2013 & 804 & 0.767 & 0.756 & 0.100 \\
2014 & 602 & 0.787 & 0.785 & 0.118 \\
Total & 574 & 0.874 & 0.895 & 0.131 \\
& 3475 & 0.795 & 0.800 & 0.134
\end{tabular}

\begin{tabular}{cccc}
\multicolumn{4}{c}{ Transaction Data } \\
\hline $\mathrm{N}$ & Purchase Price \% NAV & median & SD \\
\hline 9 & 0.733 & 0.737 & 0.178 \\
272 & 1.089 & 1.175 & 0.282 \\
217 & 0.993 & 0.950 & 0.434 \\
264 & 0.781 & 0.750 & 0.366 \\
213 & 0.544 & 0.526 & 0.187 \\
179 & 0.843 & 0.850 & 0.260 \\
259 & 0.822 & 0.803 & 0.218 \\
281 & 0.832 & 0.841 & 0.317 \\
222 & 0.866 & 0.833 & 0.236 \\
310 & 0.932 & 0.946 & 0.248 \\
2226 & 0.862 & 0.856 & 0.323
\end{tabular}

Panel C. Average Fund and Transaction Size

\begin{tabular}{|c|c|c|c|c|c|c|c|c|c|c|}
\hline & \multirow[b]{2}{*}{$\mathrm{N}$} & \multicolumn{3}{|c|}{ Fund Size (\$ Million) } & \multicolumn{3}{|c|}{ Transaction Size (\$ Million) } & \multicolumn{3}{|c|}{ Fund Size } \\
\hline & & Mean & Med & SD & Mean & Med & SD & Mean & Med & SD \\
\hline Buyout Funds & 1052 & $\$ 3,726.0$ & $\$ 1,800.0$ & $\$ 6,441.8$ & $\$ 12.6$ & $\$ 4.9$ & $\$ 25.2$ & 0.016 & 0.003 & 0.122 \\
\hline Venture Funds & 607 & $\$ 458.9$ & $\$ 364.6$ & $\$ 389.3$ & $\$ 3.3$ & $\$ 1.8$ & $\$ 4.5$ & 0.011 & 0.005 & 0.016 \\
\hline RE. FOF, Other & 253 & $\$ 1,308.2$ & $\$ 730.3$ & $\$ 1,584.3$ & $\$ 8.4$ & $\$ 3.8$ & $\$ 12.0$ & 0.016 & 0.006 & 0.026 \\
\hline
\end{tabular}


Table 2. Secondary Market Bid and Transaction Prices by Fund Size and Fund Experience

Panel A reports summary statistics on fund size and annualized IRRs for the universe of funds reported in the Preqin database. Panel B reports the same set of summary statistics for the intersection of funds in the Preqin and transaction sample.

Panel A. Summary Statistics on the Preqin Universe.

\begin{tabular}{lcccc} 
& \multicolumn{4}{c}{ Fund Size $(\$ \mathrm{M})$} \\
& $\mathrm{N}$ & mean & median & $\mathrm{SD}$ \\
\cline { 2 - 5 } Buyout & 787 & 1643.0 & 700.0 & 2658.3 \\
Venture & 710 & 386.2 & 247.5 & 447.4 \\
Other & 1043 & 1041.2 & 530.0 & 1491.3 \\
& & & & \\
Total & 2540 & 1044.6 & 460.5 & 1840.8 \\
\hline
\end{tabular}

\begin{tabular}{cccc}
\hline \multicolumn{4}{c}{ Annualized IRR } \\
$\mathrm{N}$ & mean & median & $\mathrm{SD}$ \\
\hline 787 & 0.107 & 0.110 & 0.170 \\
710 & 0.075 & 0.061 & 0.203 \\
1043 & 0.098 & 0.093 & 0.161 \\
& & & \\
2540 & 0.094 & 0.090 & 0.177 \\
\hline
\end{tabular}

Panel B. Summary Statistics on the Preqin - Transaction Sample Intersection

\begin{tabular}{lcccc}
\cline { 2 - 5 } & \multicolumn{4}{c}{ Fund Size $(\$ \mathrm{M})$} \\
Buyout & $\mathrm{N}$ & mean & median & $\mathrm{SD}$ \\
\cline { 2 - 5 } Venture & 213 & 3253.2 & 1900.0 & 3877.5 \\
Other & 132 & 546.3 & 424.4 & 488.3 \\
& 90 & 2076.4 & 1093.0 & 2485.0 \\
Total & & & & \\
\hline
\end{tabular}

\begin{tabular}{cccc}
\hline \multicolumn{4}{c}{ Annualized IRR } \\
$\mathrm{N}$ & mean & median & $\mathrm{SD}$ \\
\hline 213 & 0.124 & 0.116 & 0.110 \\
132 & 0.068 & 0.036 & 0.211 \\
90 & 0.101 & 0.105 & 0.116 \\
& & & \\
435 & 0.102 & 0.092 & 0.151 \\
\hline
\end{tabular}


Table 3. Secondary Market Bid and Transaction Prices by Fund Age, Through Time

This table reports summary statistics on secondary market transactions by fund age at the time of a secondary market transaction. Panel $A$ reports statistics for buyout funds while Panels $B$ and $C$ report prices and deal counts for venture and other funds, respectively. Panel $D$ reports average fund age, in quarters, at the time of transaction, by year.

\begin{tabular}{|c|c|c|c|}
\hline \multicolumn{4}{|c|}{$\%$ of NAV for Completed Transactions } \\
\hline & \multicolumn{3}{|c|}{ Fund Age at Time of Transaction } \\
\hline & 0-3 Years & 4-9 Years & $>=10$ Years \\
\hline \multicolumn{4}{|c|}{ Panel A. Buyout Funds } \\
\hline Mean & 0.718 & 0.909 & 0.822 \\
\hline Median & 0.709 & 0.909 & 0.803 \\
\hline Std Dev. & 0.320 & 0.238 & 0.421 \\
\hline $\mathrm{N}$ & 84 & 462 & 175 \\
\hline \multicolumn{4}{|c|}{ Panel B. Venture Funds } \\
\hline Mean & 0.933 & 0.984 & 0.896 \\
\hline Median & 0.934 & 0.948 & 0.835 \\
\hline Std Dev. & 0.369 & 0.339 & 0.482 \\
\hline $\mathrm{N}$ & 21 & 167 & 161 \\
\hline \multicolumn{4}{|c|}{ Panel C. Real Estate, Fund of Funds, Other } \\
\hline Mean & 0.789 & 0.895 & 0.753 \\
\hline Median & 0.900 & 0.900 & 0.733 \\
\hline Std Dev. & 0.320 & 0.149 & 0.297 \\
\hline $\mathrm{N}$ & 23 & 75 & 18 \\
\hline
\end{tabular}

Panel D. Fund Age at Time of Transaction

Average Fund Age at the Time of Transaction (\# Quarters)

\begin{tabular}{crrrr}
\hline Year & \multicolumn{1}{c}{ Count } & \multicolumn{1}{c}{ Mean } & Median & Std. Dev \\
\hline 2006 & 124 & 28.6 & 25 & 14.5 \\
2007 & 108 & 32.1 & 31 & 13.0 \\
2008 & 149 & 27.8 & 30 & 13.4 \\
2009 & 100 & 19.5 & 14 & 13.0 \\
2010 & 117 & 22.0 & 16 & 13.5 \\
2011 & 158 & 26.7 & 22 & 11.8 \\
2012 & 170 & 31.1 & 26 & 13.0 \\
2013 & 127 & 40.2 & 35 & 16.4 \\
2014 & 133 & 37.6 & 35 & 14.0 \\
\hline
\end{tabular}


Table 4. Characterizing the Attributes of Funds that Sell.

This table presents results of probit regressions where the dependent variable is equal to one if a fund transacted in the secondary market. The sample consists of a quarterly panel of funds in the Preqin universe. Buyout and Venture indicator variables are estimated relative to the "other" category of funds. Log fund size is the natural log of the fund size. The age indicator variables measure the age of funds, with funds 49 years old serving as the omitted category. Fund PME measures the performance of the fund in each quarter. We assume the fund's NAV in each quarter as the liquidation value of the fund when calculating fund PME's. Number of funds in fund family measures the total number of funds reported in Preqin for a given General Partner. Equity market pricelearnings ratio measures the aggregate equity market price/earnings ratio in a given quarter. Columns (2) and (3) include quarter-of-transaction fixed effects. Column (3) also includes year-of-fund-origination vintage fixed effects. Standard errors are clustered by quarter.

\begin{tabular}{|c|c|c|c|}
\hline & \multicolumn{3}{|c|}{ Dependent Variable: Fund Sold in Secondary Market Indicator } \\
\hline & $(1)$ & $(2)$ & (3) \\
\hline Buyout Indicator & $\begin{array}{c}0.551 * * * \\
(9.489)\end{array}$ & $\begin{array}{c}0.537 * * * \\
(8.678)\end{array}$ & $\begin{array}{c}0.518^{* * *} \\
(8.054)\end{array}$ \\
\hline Venture Indicator & $\begin{array}{c}0.747 * * * \\
(9.815)\end{array}$ & $\begin{array}{c}0.722 * * * \\
(9.602)\end{array}$ & $\begin{array}{c}0.663 * * * \\
(8.571)\end{array}$ \\
\hline Log Fund Size & $\begin{array}{c}0.394 * * * \\
(14.838)\end{array}$ & $\begin{array}{c}0.438 * * * \\
(18.562)\end{array}$ & $\begin{array}{c}0.435 * * * \\
(18.811)\end{array}$ \\
\hline$<=3$ Yr. Old Fund Indicator & $\begin{array}{c}-0.381 * * * \\
(-4.555)\end{array}$ & $\begin{array}{c}-0.471 * * * \\
(-5.003)\end{array}$ & $\begin{array}{c}-0.294 * * \\
(-2.356)\end{array}$ \\
\hline 4-9 Yr. Old Fund Indicator (omitted) & & & \\
\hline$>=10$ Yr. Old Fund Indicator & $\begin{array}{c}0.033 \\
(0.434)\end{array}$ & $\begin{array}{c}0.079 \\
(1.067)\end{array}$ & $\begin{array}{c}-0.063 \\
(-0.759)\end{array}$ \\
\hline Fund PME & $\begin{array}{c}-0.076 \\
(-1.386)\end{array}$ & $\begin{array}{c}-0.137 * * \\
(-2.419)\end{array}$ & $\begin{array}{c}-0.151 * * * \\
(-2.668)\end{array}$ \\
\hline Number of Funds in Fund Family & $\begin{array}{c}-0.002 \\
(-0.532)\end{array}$ & $\begin{array}{c}-0.004 \\
(-1.076)\end{array}$ & $\begin{array}{c}-0.004 \\
(-1.242)\end{array}$ \\
\hline Equity Market Price/Earnings Ratio & $\begin{array}{c}-0.011 \\
(-0.596)\end{array}$ & & \\
\hline Quarter Fixed Effects & No & Yes & Yes \\
\hline Vintage Fixed Effects & No & No & Yes \\
\hline Std. Error Clustered by Quarter & Yes & Yes & Yes \\
\hline Observations & 53,975 & 53,975 & 53,975 \\
\hline Psuedo-R2 & 0.146 & 0.197 & 0.203 \\
\hline
\end{tabular}


Table 5. Average IRRs to Buyers and Sellers in the Secondary Market.

This table reports average IRRs to LPs over two different scenarios. Secondary Market Seller Returns are realized returns to LPs that invested in a fund at fund inception then sold their position in the fund through the secondary market. Secondary Market Buyer Returns are realized returns to LPs that bought into a fund through the secondary market then held the fund until the funds liquidation. In all return calculations, in circumstances where the fund has not liquidated we use the last available Preqin NAV as the assumed liquidation value. T-statistics are calculated with standard errors that are clustered by quarter of transaction. Reported returns are equally weighted. Unreported value weighted returns are qualitatively similar.

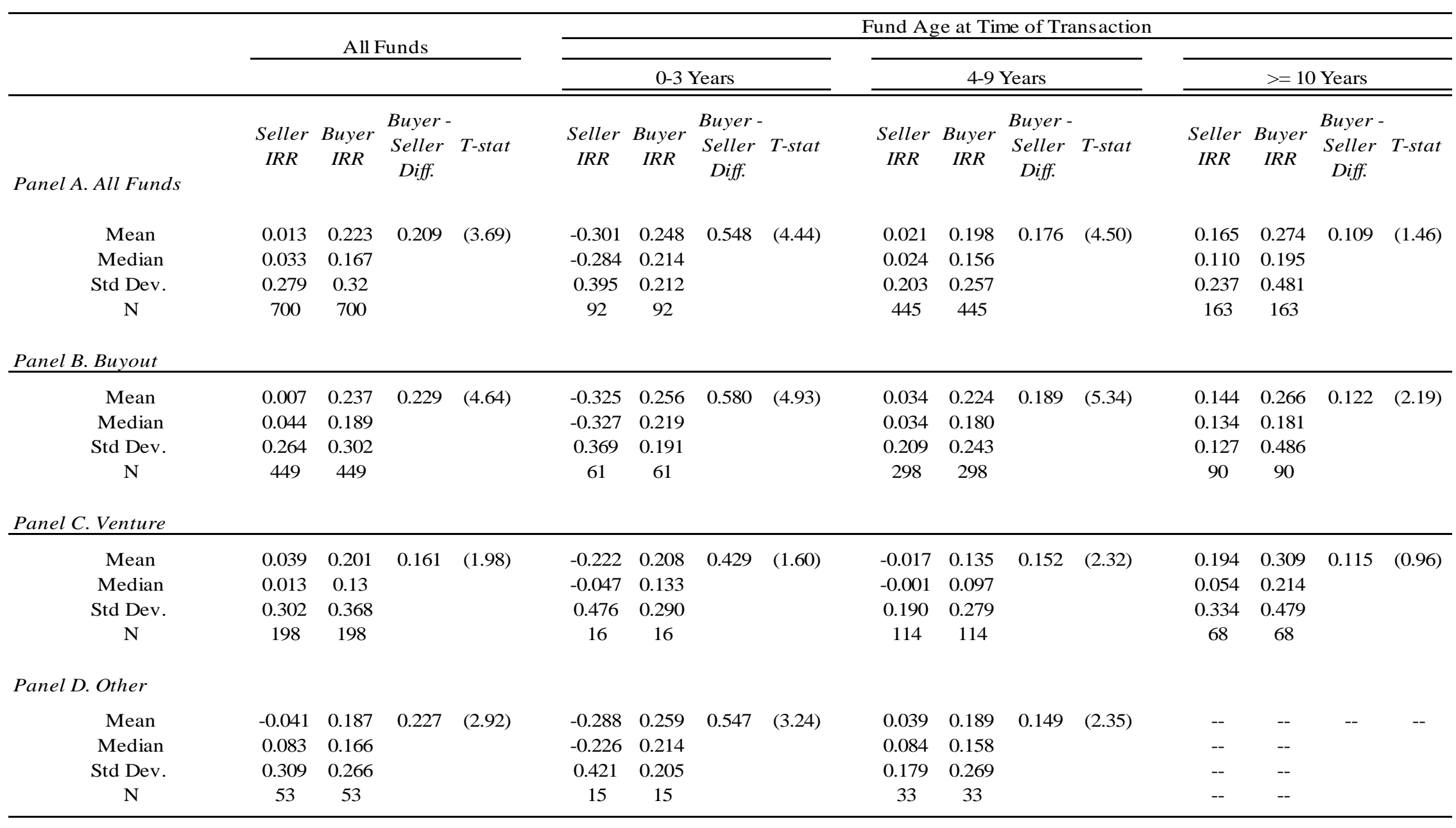


Table 6. Annualized PMEs for Buyers and Sellers in the Secondary Market

This table reports annualized PMEs to LPs over two different scenarios. Seller annualized PMEs are realized returns to LPs that invested in a fund at fund inception then sold their position in the fund through the secondary market. Buyer annualized PMEs are realized PMEs for LPs that bought into a fund through the secondary market then held the fund until the funds liquidation. In all return calculations, in circumstances where the fund has not liquidated we use the last available Preqin NAV as the assumed liquidation value. T-statistics are calculated with standard errors that are clustered by quarter of transaction. Reported PMEs are equally weighted. Unreported value weighted PMEs are qualitatively similar.

\begin{tabular}{|c|c|c|c|c|c|c|c|c|c|c|c|c|c|c|c|c|}
\hline & \multicolumn{4}{|c|}{ All Funds } & \multicolumn{12}{|c|}{ Fund Age at Time of Transaction } \\
\hline & & & & & \multicolumn{4}{|c|}{ 0-3 Years } & \multicolumn{4}{|c|}{ 4-9 Years } & \multicolumn{4}{|c|}{$>=10$ Years } \\
\hline & $\begin{array}{c}\text { Seller } \\
\text { Annualized } \\
\text { PME }\end{array}$ & $\begin{array}{c}\text { Buyer } \\
\text { Annualized } \\
\text { PME }\end{array}$ & $\begin{array}{c}\text { Buyer - } \\
\text { Seller } \\
\text { Diff. }\end{array}$ & $T$-stat & $\begin{array}{c}\text { Seller } \\
\text { Annualized } \\
\text { PME }\end{array}$ & $\begin{array}{c}\text { Buyer } \\
\text { Annualized } \\
\text { PME }\end{array}$ & $\begin{array}{c}\text { Buyer - } \\
\text { Seller } \\
\text { Diff. }\end{array}$ & T-stat & $\begin{array}{c}\text { Seller } \\
\text { Annualized } \\
\text { PME }\end{array}$ & $\begin{array}{c}\text { Buyer } \\
\text { Annualized } \\
\text { PME }\end{array}$ & $\begin{array}{l}\text { Buyer - } \\
\text { Seller } \\
\text { Diff. }\end{array}$ & T-stat & $\begin{array}{c}\text { Seller } \\
\text { Annualized } \\
\text { PME }\end{array}$ & $\begin{array}{c}\text { Buyer } \\
\text { Annualized } \\
\text { PME }\end{array}$ & $\begin{array}{l}\text { Buyer - } \\
\text { Seller } \\
\text { Diff. }\end{array}$ & T-stat \\
\hline \multicolumn{17}{|c|}{ Panel A. All Funds } \\
\hline $\begin{array}{c}\text { Mean } \\
\text { Median } \\
\text { Std Dev. } \\
\text { N }\end{array}$ & $\begin{array}{c}0.974 \\
0.992 \\
0.107 \\
700\end{array}$ & $\begin{array}{c}1.023 \\
1.011 \\
0.118 \\
700\end{array}$ & 0.049 & (2.61) & $\begin{array}{c}0.854 \\
0.909 \\
0.196 \\
92\end{array}$ & $\begin{array}{c}1.100 \\
1.070 \\
0.254 \\
92\end{array}$ & 0.245 & (3.33) & $\begin{array}{c}0.983 \\
0.988 \\
0.075 \\
445\end{array}$ & $\begin{array}{c}1.013 \\
1.007 \\
0.080 \\
445\end{array}$ & 0.030 & (3.34) & $\begin{array}{c}1.017 \\
1.021 \\
0.049 \\
163\end{array}$ & $\begin{array}{c}1.008 \\
1.008 \\
0.053 \\
163\end{array}$ & -0.008 & $(1.20)$ \\
\hline \multicolumn{17}{|l|}{ Panel B. Buyout } \\
\hline $\begin{array}{c}\text { Mean } \\
\text { Median } \\
\text { Std Dev. } \\
\text { N }\end{array}$ & $\begin{array}{c}0.979 \\
1.003 \\
0.107 \\
449\end{array}$ & $\begin{array}{c}1.027 \\
1.012 \\
0.105 \\
449\end{array}$ & 0.047 & (2.38) & $\begin{array}{c}0.850 \\
0.873 \\
0.185 \\
61\end{array}$ & $\begin{array}{c}1.102 \\
1.077 \\
0.195 \\
61\end{array}$ & 0.252 & (3.86) & $\begin{array}{c}0.992 \\
0.998 \\
0.075 \\
298\end{array}$ & $\begin{array}{c}1.019 \\
1.008 \\
0.080 \\
298\end{array}$ & 0.026 & $(2.40)$ & $\begin{array}{c}1.023 \\
1.030 \\
0.034 \\
90\end{array}$ & $\begin{array}{c}1.001 \\
1.008 \\
0.058 \\
90\end{array}$ & -0.022 & $(4.25)$ \\
\hline \multicolumn{17}{|l|}{ Panel C. Venture } \\
\hline $\begin{array}{c}\text { Mean } \\
\text { Median } \\
\text { Std Dev. } \\
\text { N }\end{array}$ & $\begin{array}{c}0.970 \\
0.979 \\
0.097 \\
198\end{array}$ & $\begin{array}{c}1.012 \\
1.004 \\
0.148 \\
198\end{array}$ & 0.041 & (1.81) & $\begin{array}{c}0.874 \\
0.950 \\
0.237 \\
16\end{array}$ & $\begin{array}{c}1.089 \\
0.997 \\
0.470 \\
16\end{array}$ & 0.214 & $(0.94)$ & $\begin{array}{c}0.962 \\
0.967 \\
0.065 \\
114\end{array}$ & $\begin{array}{c}0.997 \\
0.995 \\
0.080 \\
114\end{array}$ & 0.035 & (3.73) & $\begin{array}{c}1.008 \\
0.995 \\
0.063 \\
68\end{array}$ & $\begin{array}{c}1.018 \\
1.011 \\
0.045 \\
68\end{array}$ & 0.011 & $(0.77)$ \\
\hline \multicolumn{17}{|l|}{ Panel D. Other } \\
\hline $\begin{array}{c}\text { Mean } \\
\text { Median } \\
\text { Std Dev. } \\
\text { N }\end{array}$ & $\begin{array}{c}0.942 \\
0.990 \\
0.138 \\
53\end{array}$ & $\begin{array}{c}1.036 \\
1.020 \\
0.101 \\
53\end{array}$ & 0.094 & (2.86) & $\begin{array}{c}0.849 \\
0.954 \\
0.203 \\
15\end{array}$ & $\begin{array}{c}1.100 \\
1.085 \\
0.143 \\
15\end{array}$ & 0.251 & $(3.25)$ & $\begin{array}{c}0.973 \\
0.997 \\
0.082 \\
33\end{array}$ & $\begin{array}{c}1.015 \\
1.017 \\
0.070 \\
33\end{array}$ & 0.041 & $(1.86)$ & $\begin{array}{l}-- \\
-- \\
-- \\
--\end{array}$ & $\begin{array}{l}-- \\
-- \\
-- \\
--\end{array}$ & -- & -- \\
\hline
\end{tabular}


Table 7. The Association of Fund Attributes with \%NAV Paid in Transactions.

This table reports the results of OLS regressions where the dependent variable in each model is the \%NAV paid at the time of a transaction. Venture Indicator and Buyout Indicator are equal to one for venture and buyout funds, respectively. "Other" funds serve as the omitted group. Equity market price/earnings ratio measures the aggregate equity market price/earnings ratio in a given quarter. Number of funds in fund family measures the total number of funds in a GP family of funds. Number of bids on fund measures the number of bids on a given fund prior to the close of the transaction. Log transaction size is the log of the transaction size and transaction size / fund size measures the transaction size scaled by fund size. We construct a series of indicator variables for fund age. Funds between 4 and 9 years old are the omitted category for the fund age indicators. Portfolio bid indicator identifies transactions where an LP sold or bought multiple funds in a given transaction. Fund-of-funds buy indicator and fund-of-funds sell indicator identify the buy and sell transactions involving funds identified as funds-of-funds. Fund PME measures the performance of the fund at the time of a transaction, using the fund's NAV at that time as if it were a liquidating distribution. All standard errors are clustered at the transaction-quarter level.

\begin{tabular}{|c|c|c|c|c|c|c|c|}
\hline & \multicolumn{7}{|c|}{ Dependent Var: \% NAV Paid at Transaction } \\
\hline & \multicolumn{4}{|c|}{ Full Sample } & \multirow{2}{*}{$\begin{array}{c}\begin{array}{c}0-3 \mathrm{Yr} \\
\text { Sample }\end{array} \\
(5)\end{array}$} & \multirow{2}{*}{$\begin{array}{c}\begin{array}{c}\text { 4-9 Yr } \\
\text { Sample }\end{array} \\
(6)\end{array}$} & \multirow{2}{*}{$\begin{array}{c}>10 \mathrm{Yr} \\
\text { Sample } \\
(7)\end{array}$} \\
\hline & $(1)$ & $(2)$ & (3) & (4) & & & \\
\hline Venture Indicator & $\begin{array}{c}0.068 \\
(1.322)\end{array}$ & $\begin{array}{c}0.060 \\
(1.558)\end{array}$ & $\begin{array}{c}0.047 \\
(1.256)\end{array}$ & $\begin{array}{c}0.165 * * * \\
(4.108)\end{array}$ & $\begin{array}{c}0.157 \\
(1.526)\end{array}$ & $\begin{array}{c}0.043 \\
(1.046)\end{array}$ & $\begin{array}{c}0.047 \\
(0.855)\end{array}$ \\
\hline Buyout Indicator & $\begin{array}{c}0.030 \\
(1.002)\end{array}$ & $\begin{array}{c}0.016 \\
(0.669)\end{array}$ & $\begin{array}{c}0.022 \\
(0.766)\end{array}$ & $\begin{array}{c}0.020 \\
(0.655)\end{array}$ & $\begin{array}{c}0.046 \\
(0.633)\end{array}$ & $\begin{array}{c}0.005 \\
(0.228)\end{array}$ & $\begin{array}{c}0.012 \\
(0.188)\end{array}$ \\
\hline$<=3$ Yr. Old Fund Indicator & $\begin{array}{c}-0.125 * * \\
(-2.529)\end{array}$ & $\begin{array}{c}0.002 \\
(0.049)\end{array}$ & $\begin{array}{c}0.011 \\
(0.323)\end{array}$ & $\begin{array}{c}0.020 \\
(0.644)\end{array}$ & & & \\
\hline 4-9 Yr. Old Fund Indicator (omitted) & & & & & & & \\
\hline$>=10$ Yr. Old Fund Indicator & $\begin{array}{c}-0.111^{* * *} * \\
(-3.076)\end{array}$ & $\begin{array}{c}-0.102 * * * \\
(-3.626)\end{array}$ & $\begin{array}{c}-0.073 * * * \\
(-3.798)\end{array}$ & $\begin{array}{c}-0.101 * * * \\
(-4.266)\end{array}$ & & & \\
\hline Equity Market Price/Earnings Ratio & & $\begin{array}{c}0.042 * * * \\
(11.607)\end{array}$ & & & & & \\
\hline Number of Funds in Fund Family & & $\begin{array}{c}-0.003 \\
(-1.338)\end{array}$ & $\begin{array}{c}-0.003 \\
(-1.275)\end{array}$ & $\begin{array}{c}-0.005^{* *} \\
(-2.519)\end{array}$ & $\begin{array}{c}-0.006 \\
(-1.094)\end{array}$ & $\begin{array}{c}-0.000 \\
(-0.173)\end{array}$ & $\begin{array}{c}-0.003 \\
(-0.552)\end{array}$ \\
\hline Log Fund Size & & $\begin{array}{c}0.038 * * * \\
(3.767)\end{array}$ & $\begin{array}{c}0.037 * * * \\
(3.804)\end{array}$ & $\begin{array}{c}0.061 * * * \\
(4.770)\end{array}$ & $\begin{array}{c}0.012 \\
(0.542)\end{array}$ & $\begin{array}{c}0.041 * * * \\
(3.543)\end{array}$ & $\begin{array}{c}0.048 * * * \\
(3.317)\end{array}$ \\
\hline Transaction Size / Fund Size & & $\begin{array}{c}1.161 * * \\
(2.387)\end{array}$ & $\begin{array}{c}1.215^{* *} \\
(2.405)\end{array}$ & $\begin{array}{c}2.367 * * * \\
(2.870)\end{array}$ & $\begin{array}{c}1.383 \\
(0.977)\end{array}$ & $\begin{array}{c}0.877 * * \\
(2.242)\end{array}$ & $\begin{array}{c}4.376^{* *} \\
(2.695)\end{array}$ \\
\hline Portfolio Bid Indicator & & $\begin{array}{c}0.002 \\
(0.091)\end{array}$ & $\begin{array}{c}0.021 \\
(1.111)\end{array}$ & $\begin{array}{c}0.028 \\
(1.427)\end{array}$ & $\begin{array}{c}0.015 \\
(0.183)\end{array}$ & $\begin{array}{c}0.021 \\
(1.222)\end{array}$ & $\begin{array}{c}-0.007 \\
(-0.189)\end{array}$ \\
\hline Fund-of-funds Buy Indicator & & $\begin{array}{c}0.023 \\
(1.330)\end{array}$ & $\begin{array}{c}-0.013 \\
(-1.047)\end{array}$ & $\begin{array}{c}-0.031 \\
(-1.518)\end{array}$ & $\begin{array}{c}-0.002 \\
(-0.065)\end{array}$ & $\begin{array}{c}-0.015 \\
(-0.983)\end{array}$ & $\begin{array}{c}-0.011 \\
(-0.374)\end{array}$ \\
\hline Fund-of-funds Sell Indicator & & $\begin{array}{c}0.012 \\
(0.393)\end{array}$ & $\begin{array}{c}-0.025 \\
(-1.196)\end{array}$ & $\begin{array}{c}-0.008 \\
(-0.376)\end{array}$ & $\begin{array}{c}-0.005 \\
(-0.111)\end{array}$ & $\begin{array}{c}-0.013 \\
(-0.462)\end{array}$ & $\begin{array}{c}-0.010 \\
(-0.215)\end{array}$ \\
\hline Number of Bids on Fund & & & & $\begin{array}{c}0.004 \\
(1.406)\end{array}$ & & & \\
\hline PME at time of Transaction & & & & $\begin{array}{c}0.052 * * * \\
(3.254)\end{array}$ & & & \\
\hline Transaction Quarter Fixed Effects & No & No & Yes & Yes & Yes & Yes & Yes \\
\hline Std. Err. Clustered by Transaction Quarter & Yes & Yes & Yes & Yes & Yes & Yes & Yes \\
\hline Observations & 2,073 & 2,073 & 2,073 & 843 & 288 & 1,185 & 600 \\
\hline R-squared & 0.034 & 0.214 & 0.321 & 0.418 & 0.478 & 0.344 & 0.191 \\
\hline
\end{tabular}


Table 8. Difference between Buyer and Seller IRRs and PMEs

This table reports the results of OLS regressions where the dependent variable in models (1)-(3) is the difference in annualized IRRs of buyers and sellers in a given transaction. Models (4)-(6) report differences in buyer and seller returns for annualized PMEs. Venture Indicator and Buyout Indicator are equal to one for venture and buyout funds, respectively. "Other" funds serve as the omitted group. Equity market price/earnings ratio measures the aggregate equity market price/earnings ratio in a given quarter. Number of funds in fund family measures the total number of funds in a GP's family of funds. Number of bids on fund measures the number of bids on a given fund prior to the close of the transaction. Log transaction size is the log of the transaction size and transaction size / fund size measures the transaction size scaled by fund size. We construct a series of indicator variables for fund age. Funds between 4 and 9 years old are the omitted category for the fund age indicators. Portfolio bid indicator identifies transactions where an LP sold or bought multiple funds in a given transaction. Fund-of-funds buy indicator and fund-of-funds sell indicator identify the buy and sell transactions involving funds identified as funds-of-funds. Fund PME measures the performance of the fund at the time of a transaction, using the fund's NAV at that time as if it were a liquidating distribution. All standard errors are clustered at the transaction-quarter level.

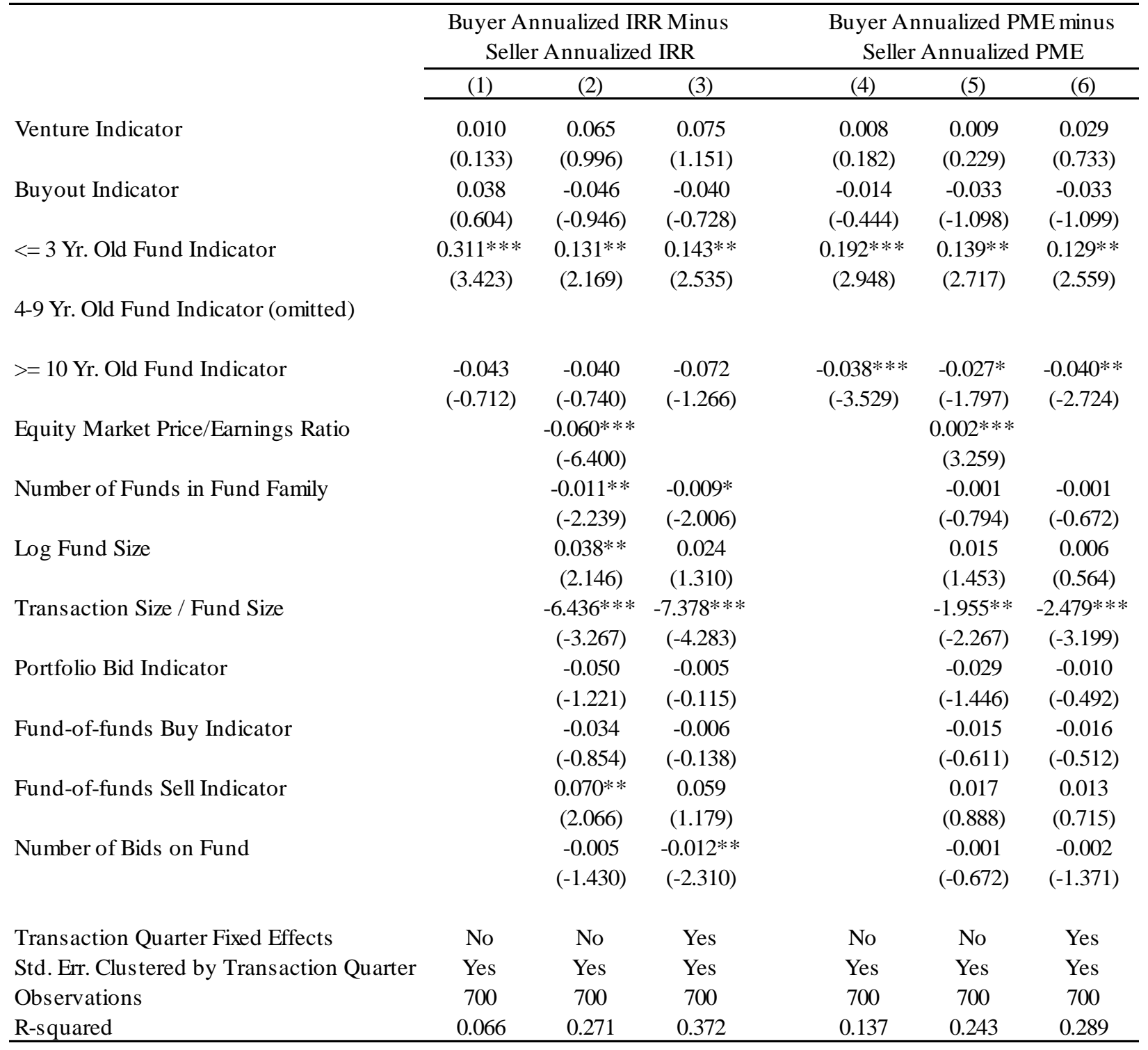


Table 9. Transaction Counts of Fund-of-Funds and Other Investors

This table reports buyer and seller transaction counts by LP type, fund-of-funds and other LPs. Other LPs include pensions, endowments, trusts, foundations, financial institutions, sovereign funds, and state investment funds. Panel's $A, B$, and $C$ tabulate counts for buyout, venture, and other funds, respectively. 
Panel A. Transaction Counts - Buyout Funds

\begin{tabular}{ccccccc}
\hline & Buy Transactions & & & \multicolumn{3}{c}{ Sell Transactions } \\
\cline { 5 - 6 } Year & Fund-of-funds & Other & & Year & Fund-of-funds & Other \\
2006 & 39 & 5 & & 2006 & 8 & 36 \\
2007 & 41 & 6 & 2007 & $<5$ & 47 \\
2008 & 91 & 4 & 2008 & 41 & 54 \\
2009 & 43 & 13 & 2009 & 27 & 29 \\
2010 & 66 & 24 & 2010 & 27 & 63 \\
2011 & 112 & 20 & 2011 & 60 & 72 \\
2012 & 115 & 8 & 2012 & 39 & 84 \\
2013 & 52 & 11 & 2013 & 20 & 43 \\
2014 & 48 & 23 & 2014 & 17 & 54 \\
Total & 607 & 114 & Total & 239 & 482 \\
\hline
\end{tabular}

Panel B. Transaction Counts - Venture Funds

\begin{tabular}{ccccccc}
\hline & Buy Transactions & & \multicolumn{3}{c}{ Sell Transactions } \\
\cline { 5 - 6 } Year & Fund-of-funds & Other & & Year & Fund-of-funds & Other \\
2006 & 68 & 7 & & 2006 & 29 & 46 \\
2007 & 51 & $<5$ & & 2007 & $<5$ & 52 \\
2008 & 43 & $<5$ & 2008 & 18 & 27 \\
2009 & 35 & $<5$ & 2009 & 6 & 30 \\
2010 & 14 & $<5$ & 2010 & 10 & 6 \\
2011 & 14 & $<5$ & 2011 & 11 & $<5$ \\
2012 & 29 & $<5$ & 2012 & 21 & 11 \\
2013 & 40 & $<5$ & 2013 & 23 & 19 \\
2014 & 30 & $<5$ & 2014 & $<5$ & 33 \\
Total & 324 & 25 & & & & 227 \\
\hline
\end{tabular}

Panel C. Transaction Counts - Other Funds

\begin{tabular}{ccccccc}
\hline & Buy Transactions & & & \multicolumn{3}{c}{ Sell Transactions } \\
\cline { 5 - 7 } Year & Fund-of-funds & Other & & Year & Fund-of-funds & Other \\
2006 & $<5$ & $<5$ & & 2006 & $<5$ & $<5$ \\
2007 & 6 & $<5$ & & 2007 & $<5$ & 6 \\
2008 & $<5$ & 7 & 2008 & 6 & $<5$ \\
2009 & $<5$ & 6 & 2009 & 5 & $<5$ \\
2010 & 5 & 6 & 2010 & $<5$ & 8 \\
2011 & 7 & 5 & 2011 & $<5$ & 8 \\
2012 & 13 & $<5$ & 2012 & 7 & 8 \\
2013 & 20 & $<5$ & 2013 & 5 & 17 \\
2014 & 24 & $<5$ & 2014 & $<5$ & 25 \\
Total & 82 & 34 & & & 82 \\
\hline
\end{tabular}


Table 10. Buyers and Sellers by Type and Fund Age.

This table reports buyer and seller transaction counts by fund age at the time of transaction and by LP type, fund-of-funds and other LPs. Other LPs include pensions, endowments, trusts, foundations, financial institutions, sovereign funds, and state investment funds. Panel's $A, B, C$, and $D$ tabulate counts for all fund types, buyout, venture, and other funds, respectively.

\begin{tabular}{|c|c|c|c|c|c|c|}
\hline & \multicolumn{3}{|c|}{ Buy Transaction } & \multicolumn{3}{|c|}{ Sell Transaction } \\
\hline & $\begin{array}{c}0-3 \text { Yr. Old } \\
\text { Fund }\end{array}$ & $\begin{array}{c}\text { 4-9 Yr. Old } \\
\text { Fund }\end{array}$ & $\begin{array}{l}>=10 \text { Yr. } \\
\text { Old Fund }\end{array}$ & $\begin{array}{c}0-3 \text { Yr. Old } \\
\text { Fund }\end{array}$ & $\begin{array}{c}\text { 4-9 Yr. Old } \\
\text { Fund }\end{array}$ & $\begin{array}{l}>=10 \text { Yr. } \\
\text { Old Fund }\end{array}$ \\
\hline \multicolumn{7}{|c|}{ Panel A. All Funds } \\
\hline Other & 31 & 112 & 30 & 75 & 511 & 205 \\
\hline Fund-of-funds & 97 & 592 & 324 & 53 & 193 & 149 \\
\hline \multicolumn{7}{|l|}{ Panel B. Buyout } \\
\hline Other & 16 & 82 & 16 & 56 & 324 & 102 \\
\hline Fund-of-funds & 68 & 380 & 159 & 28 & 138 & 73 \\
\hline \multicolumn{7}{|c|}{ Panel C. Venture } \\
\hline Other & $<5$ & 13 & 11 & 7 & 128 & 92 \\
\hline Fund-of-funds & 20 & 154 & 150 & 14 & 39 & 69 \\
\hline \multicolumn{7}{|l|}{ Panel D. Other } \\
\hline Other & 14 & 17 & $<5$ & 12 & 59 & 11 \\
\hline Fund-of-funds & 9 & 58 & 15 & 11 & 16 & 7 \\
\hline
\end{tabular}

